Article

\title{
Precipitation of Inorganic Salts in Mitochondrial Matrix
}

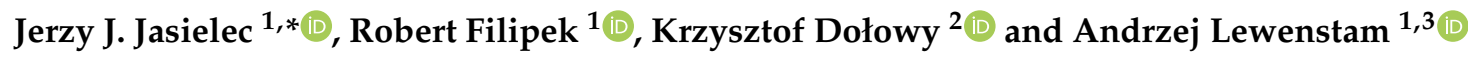 \\ 1 Faculty of Materials Science and Ceramics, AGH University of Science and Technology, Al. Mickiewicza 30, \\ 30-059 Krakow, Poland; rof@agh.edu.pl \\ 2 Department of Physics and Biophysics, Warsaw University of Life Sciences-SGGW, Nowoursynowska 159, \\ 02-776 Warszawa, Poland; krzysztof_dolowy@sggw.edu.pl \\ 3 Johan Gadolin Process Chemistry Centre, Centre of Process Analytical Chemistry and Sensor \\ Technology (ProSens), Åbo Akademi University, Biskopsgatan 8, 20500 Åbo-Turku, Finland; alewenst@abo.fi \\ * Correspondence: jasielec@agh.edu.pl; Tel.: +48-517-149-455
}

Received: 26 March 2020; Accepted: 19 April 2020; Published: 27 April 2020

\begin{abstract}
In the mitochondrial matrix, there are insoluble, osmotically inactive complexes that maintain a constant $\mathrm{pH}$ and calcium concentration. In the present paper, we examine the properties of insoluble calcium and magnesium salts, such as phosphates, carbonates and polyphosphates, which might play this role. We find that non-stoichiometric, magnesium-rich carbonated apatite, with very low crystallinity, precipitates in the matrix under physiological conditions. Precipitated salt acts as $\mathrm{pH}$ buffer, and, hence, can contribute in maintaining ATP production in ischemic conditions, which delays irreversible damage to heart and brain cells after stroke.
\end{abstract}

Keywords: mitochondrion; calcium carbonates; calcium phosphates; calcium polyphosphates; ATP production; hypoxia; ischemia; pre-conditioning

\section{Introduction}

Mitochondria are responsible for the adenosine triphosphate (ATP) production in eukaryotic organisms. They are also involved in $\mathrm{Ca}^{2+}$ signalling, lipid metabolism, heat production, reactive oxygen species production and apoptosis [1]. It is becoming increasingly apparent that mitochondria can accumulate, store and release a large amount of calcium ions under a variety of physiological and pathological conditions such as epilepsy [2], ischemia [3,4] and concussive brain injury [5].

The mitochondrial matrix is surrounded by two membranes. The outer membrane acts as a molecular sieve, while the inner membrane is ion-selective. The major function of the mitochondrial inner membrane is the formation of the electrochemical proton gradient, known as proton motive force [6], utilizing the energy produced by burning fats and sugars. The proton motive force is then used by ATP synthase to synthetize ATP from adenosine diphosphate (ADP) and inorganic phosphate. In the mitochondrial inner membrane there are numerous ion channels and ion exchangers which are involved in the transport of calcium, magnesium, potassium, sodium, protons, phosphates and other ions. The most relevant transporters in the mitochondrial inner membrane are depicted in Scheme 1. Due to the very high electric potential difference (inside negative), the mitochondrial matrix tends to accumulate calcium ions, which form a complex of calcium phosphates and carbonates. Of interest in this report are free calcium and magnesium ions, and the composition of the solid aggregates precipitating in the matrix.

The free concentration of $\mathrm{Ca}^{2+}$ and $\mathrm{Mg}^{2+}$ depends on complex chemistry which is not easy to decode because of thermodynamic and kinetic factors. The capacity of isolated mitochondria to accumulate calcium up to total matrix concentration of $0.5 \mathrm{M}$ to $0.8 \mathrm{M}$, has been established more than 
half a century ago [7-11]. However, the free calcium concentration in the range of 0.17 to $5 \mu \mathrm{M}$ has been reported by numerous studies using fluorescent $\mathrm{Ca}^{2+}$ indicators (see Table 1).

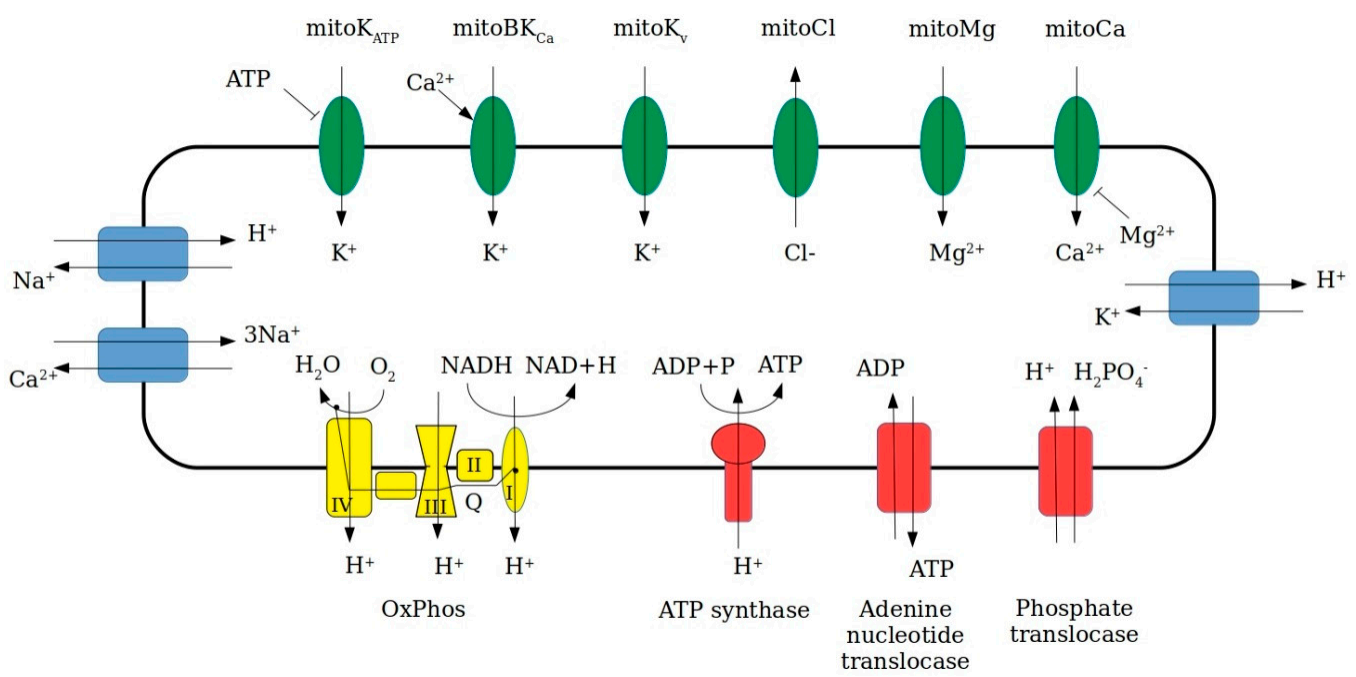

Scheme 1. Ion channels, exchangers, pumps and oxidative phosphorylation chain of the inner mitochondrial membrane: green-uniporters, blue-exchangers, yellow-four complexes of oxidative phosphorylation chain, and red-ATP synthasome. There are more than one type of mitoBK $\mathrm{Ca}_{\mathrm{a}}$ mitoKv or mitoCl channels.

In mitochondria calcium has important physiological role in stimulation of ATP synthesis via activation of several $\mathrm{Ca}^{2+}$-sensitive enzymes (pyruvate-, $\alpha$-ketoglutarate-, isocitrate dehydrogenases), ATP synthase and adenine nucleotide translocase $[12,13]$. Matrix enzymes are activated by calcium of concentration in the micromolar range, i.e., $\left[\mathrm{Ca}^{2+}\right]_{\text {matrix }}=0.5$ to $2 \mu \mathrm{M}$ [14]. Calcium can be accumulated in or released from the mitochondrion, depending on the proton motive force of the mitochondrion and cytoplasmic free calcium concentration.

In the presence of phosphates, calcium appears to form an insoluble and osmotically inactive complex, which buffer calcium concentration [7]. Amorphous granules containing calcium and phosphorus were identified within the mitochondria of osteoclasts [15], chondrocytes [16,17], osteoblasts [18], osteocytes [19-21], calcifying cartilage [22], and mineralizing bone [23-25]. It is impossible to investigate the nature of the calcium phosphates in the matrix directly, due to their instant dissociation when mitochondria are disrupted and due to their ability to transform during fixation or drying for chemical analysis [26]. Additionally, it is reasonable to presume that these complexes in the matrix are inert, to some extend at least. Even more importantly, the composition of mitochondrial granules is still largely unknown [27] and it is based on several hypotheses. Thomas and Greenawalt [28] suggested that inorganic granules found in mitochondria are a colloidal, sub-crystalline precursor of calcium-deficient hydroxyapatite. Lehninger [8] and later Nicholls and Chalmers [29] assumed the formation of amorphous tricalcium phosphate, while Kristian et al. [27] suggested the formation of brushite and non-stoichiometric amorphous calcium phosphate with $\mathrm{Ca} / \mathrm{P}$ ratio equal 1.47. Dołowy, in the most recent hypothesis [30], assumed that brushite turns into isoclasite via all intermediate forms of calcium phosphate minerals forming a polymer-like structure.

The inorganic cations present in the mitochondrial matrix include $\mathrm{Na}^{+}, \mathrm{K}^{+}, \mathrm{Ca}^{2+}$ and $\mathrm{Mg}^{2+}$. All sodium and potassium salts are soluble. Calcium and magnesium, on the other hand, can form a variety of insoluble salts. The solubility products of calcium and magnesium hydroxides are relatively high $\left(\mathrm{K}_{\mathrm{Ca}(\mathrm{OH}) 2}=6.5 \times 10^{-6}\right.$ and $\left.\mathrm{K}_{\mathrm{Mg}(\mathrm{OH}) 2}=5.6 \times 10^{-12}\right)$, therefore in considered system $\mathrm{Ca}(\mathrm{OH})_{2}$ and $\mathrm{Mg}(\mathrm{OH})_{2}$ will dissociate completely. In this work, the chemical equilibria of numerous compounds, including calcium and magnesium carbonates, phosphates and polyphosphates are intentionally examined. Based on the solubility products and other properties of these salts, we identify the reason for the $\mathrm{pH}$ buffering effect, i.e., the calcium hydroxide buffer effect in the mitochondrial matrix. 


\section{Calculations and Data}

\subsection{Mitochondrial $p H$, Ionic Concentrations and Activities}

One must realize the meaning of $\mathrm{pH}$ in the systems with very low volumes. The amount of protons can be calculated as $n_{\mathrm{H}+}=N_{A} \times V \times 10^{-\mathrm{pH}}$, where $N_{A}=6.02 \times 10^{-23}$ is the Avogadro number and $V$ represents volume. The mitochondrion is an organelle with a diameter of c.a. $1 \mu \mathrm{m}$, hence the volume of $\sim 1 \mathrm{fL}$. The mitochondrial matrix occupies $90 \%$ of mitochondrial volume. With $\mathrm{pH}_{\text {mat }}=8.2$, one obtains 3.4 protons in the matrix. This indicates that water is too weakly dissociated to be a direct donor or acceptor of protons at very low biological volumes (even if one can still define the $\mathrm{pH}$ formally) and that protons can be shuttled to reaction centers by other biomolecules, whose concentrations are not constrained by the solubility product of water [31]. These protons may be provided by carbonic or phosphoric acid or dissolution of their salts.

The molecular probes used for $\mathrm{pH}$ measurements, like e.g., SNARF-1 (seminaphtharhodafluor) [32-34] or mutants of green fluorescent protein [35-37], report their own protonation state and not the concentration of free protons in the solution.

The values of $\mathrm{pH}$ and the concentrations of inorganic ions, measured in mitochondria using various methods, are listed in Table 1 . The mitochondrion is a complex organelle in which $\mathrm{pH}$ and concentrations of ions fluctuate in response to metabolic processes and perturbations of the cytosolic environment [38]. Mitochondrial $\mathrm{pH}$ is reported to be in the range of 7.2 to 8.4 with an average value of 7.8 (see Table 1). However, when mitochondria are loaded with succinate, the $\mathrm{pH}$ can reach values close to 9 [39]. The concentration of calcium in mitochondria usually varies between 0.17 to $5 \mu \mathrm{M}$ (see Table 1). However, in the case of mitochondria of firing axon, it can reach values as high as $24 \mu \mathrm{M}$ [40]. Furthermore, the concentrations of ions are interdependent, e.g., calcium effluxes from mitochondria can depend on the concentration of sodium [41].

The driving force for the transition of dissolved matter from a supersaturated solution to the equilibrium solid phase, is given by the change of standard free energy $\Delta G^{0}=-R T \ln S$, where $S=Q / K_{s p}$ is supersaturation defined as the ratio of the ion activity product $(Q)$ of constituent ions in solution over its equilibrium solubility product $\left(K_{s p}\right)$. If $S>1$, the solution is supersaturated, and precipitation may occur. If $S<1$, the solution is undersaturated, and there will be no precipitation.

The activity product of a salt $A_{x} B_{y}$ is defined as:

$$
Q=\{A\}^{x} \times\{B\}^{y}=\gamma_{A}^{x} \times \gamma_{B}^{y} \times[A]^{x} \times[B]^{y}
$$

where $\{A\}$ and $\{B\}$ are the activities, $[A]$ and $[B]$ are the concentrations, $\gamma_{A}$ and $\gamma_{B}$ are the activity coefficients of ions $A$ and $B$, respectively.

In ideal solution, the activity coefficients of all ions equal one. However, in the concentrated solutions $\gamma_{i}$ can significantly vary from unity and strongly depends on the ionic strength of the solution defined as:

$$
I=0.5 \sum z_{i}^{2} c_{i}
$$

where $c_{i}$ is the concentration of $i$-th ion and $z_{i}$ represents its charge. It is impossible to precisely calculate the ionic strength of the mitochondrial matrix. Taking into account just the inorganic ions present in the matrix (see Table 1) and assuming similar concentration of inorganic ions, one can assume $I$ of the matrix to be in the range of 0.4 to $1 \mathrm{M}$. The extended Debye-Hückel can predict the activity coefficient in a solution with an ionic strength up to $100 \mathrm{mM}$ and Davies equation is valid up to an ionic strength of $500 \mathrm{mM}$ [42]. In this work, we use the modified Davies equation, which can correctly predict the values of the activity coefficient in solutions with ionic strength up to $1 \mathrm{M}$ [42]:

$$
\ln \gamma_{i}=-\frac{A z_{i}{ }^{2} \sqrt{I}}{1+a_{i} B \sqrt{I}}+\frac{\left(0.2-4.17 \times 10^{-5} I\right) A z_{i}{ }^{2} I}{\sqrt{1000}}
$$


where $A=\frac{\sqrt{2} F^{2} e_{0}}{8 \pi(\varepsilon R T)^{3 / 2}}$ and $B=\sqrt{\frac{2 F^{2}}{\varepsilon R T}}, F$ is the Faraday constant $(96,488.46 \mathrm{C} / \mathrm{mol}), R$ is the ideal gas constant $(8.3143 \mathrm{~J} / \mathrm{mol} / \mathrm{K}), \mathrm{T}$ is the temperature $(310 \mathrm{~K}), e_{0}$ stands for the electronic charge $\left(1.602 \times 10^{-19} \mathrm{C}\right), \varepsilon=\varepsilon_{0} \varepsilon_{r}$ is the permittivity of the medium $\left(\varepsilon_{0}=8.854 \times 10^{-12} \mathrm{~F} / \mathrm{m}, \varepsilon_{r}=80\right.$ for water), and $a_{i}$ represents the radius of hydrated ion (values according to Kielland [70]).

Table 1. Mitochondrial concentrations of selected inorganic ions.

\begin{tabular}{|c|c|c|c|c|}
\hline & Value & Measuring Technique & Type of Cell & Ref. \\
\hline \multirow{15}{*}{$\mathrm{pH}$} & 7.14 & SNARF & pig heart & [32] \\
\hline & 7.8 & BCECF & beef heart & [43] \\
\hline & $7.65-8.1$ & SNARF & beef heart & [33] \\
\hline & $8.0-8.9$ & DMO distribution & rat heart & [39] \\
\hline & $7.40-7.51$ & DMO distribution & beef heart & [44] \\
\hline & $7.74-7.95$ & ratiometric pericam & motor nerve of Drosophila fly larvae & {$[40]$} \\
\hline & 7.7 & SNARF & canine kidney (MDCK) & [34] \\
\hline & 7.64 & YFP (SypHer) & HeLa & [38] \\
\hline & $7.6-8.2$ & GFP (mtAlpHi) & HeLa & [36] \\
\hline & 7.8 & enhanced YFP & human bladder carcinoma & [45] \\
\hline & $7.7-8.2$ & $\mathrm{pH}$-sensitive GFP & (Jurkat) T lymphocyte and HEK-293 & [37] \\
\hline & 7.98 & enhanced YFP & $\mathrm{HeLa}$ & [46] \\
\hline & 7.91 & enhanced YFP & rat cardiomyocytes & [46] \\
\hline & $7.2-7.7$ & isotope distribution $\ddagger$ & rat liver & [47] \\
\hline & $7.2-8.4$ & [U-14 C]glutamate efflux & rat kidney & [48] \\
\hline \multirow{4}{*}{$\mathrm{Na}^{+}$} & 50-113 mM & CoroNa Red & canine kidney (MDCK) & [49] \\
\hline & $5 \mathrm{mM}$ & SBFI & pig heart & [50] \\
\hline & $5.1 \mathrm{mM}$ & SBFI & rat ventricular myocytes & [51] \\
\hline & $5 \mathrm{mM}$ & assumed physiol. value & - & [52] \\
\hline \multirow{4}{*}{$\mathrm{K}^{+}$} & $15 \mathrm{mM}$ & PBFI & isolated rat hepatocytes & [53] \\
\hline & $10-20 \mathrm{mM}$ & PBFI & rat heart & [54] \\
\hline & $20-60 \mathrm{mM}^{+}$ & Potentiometric ISE & rat liver & [55] \\
\hline & $150 \mathrm{mM}$ & assumed physiol. value & $-\ldots-\ldots$ & [52] \\
\hline \multirow{5}{*}{$\mathrm{Mg}^{2+}$} & $0.35 \mathrm{mM}$ & $\mathrm{Mg}^{2+}$ efflux null-point & rat hepatocytes & [56] \\
\hline & $0.9 \mathrm{mM}$ & $\mathrm{Mg}^{2+}$ efflux null-point & beef heart & [57] \\
\hline & $2.4 \mathrm{mM}$ & ${ }^{31}$ P-NMR spectroscopy & heterotrophic sycamore & [58] \\
\hline & $0.5 \mathrm{mM}$ & Fura-2 & beef heart & [59] \\
\hline & $0.8-1.5 \mathrm{mM}$ & Indo-1 and Fura-2 & rat heart & [60] \\
\hline \multirow{11}{*}{$\mathrm{Ca}^{2+}$} & $0.22 \mu \mathrm{M}$ & mito-TN-XXL & motor nerve of Drosophila fly larvae & [40] \\
\hline & $24 \mu \mathrm{M}^{*}$ & Rhod-FF/Rhod-5N & motor nerve of Drosophila fly larvae & [40] \\
\hline & $0.19-3.34 \mu \mathrm{M}$ & YC2 & HEK-293 and HeLa & [61] \\
\hline & $0.41 \mu \mathrm{M}$ & aequorin luminescence & bovine adrenal glomerulosa cells & [62] \\
\hline & $183 \mathrm{nM}$ & Indo-1 & rat heart & {$[63]$} \\
\hline & $0.1-0.6 \mu \mathrm{M}$ & Indo-1/AM & rat cardiac myocytes & {$[64]$} \\
\hline & $0.2-1.1 \mu \mathrm{M}$ & Indo-1 & rat heart & [65] \\
\hline & $0.17-0.92 \mu \mathrm{M}$ & Fura-2/AM & rat heart & [66] \\
\hline & $0.2-1.8 \mu \mathrm{M}$ & Fura-2 & rat heart & [67] \\
\hline & $0.4-2.1 \mu \mathrm{M}$ & Fura-2 & rat heart myocytes & [68] \\
\hline & $1-5 \mu \mathrm{M}$ & Fura-2/AM & rat brain & [29] \\
\hline \multirow{2}{*}{$\mathrm{Cl}-$} & $4.2 \mathrm{mM}$ & liquid chromatography & human liver & [69] \\
\hline & $0.9-22.2 \mathrm{mM}$ & liquid chromatography & human liver & [69] \\
\hline \multicolumn{5}{|c|}{ 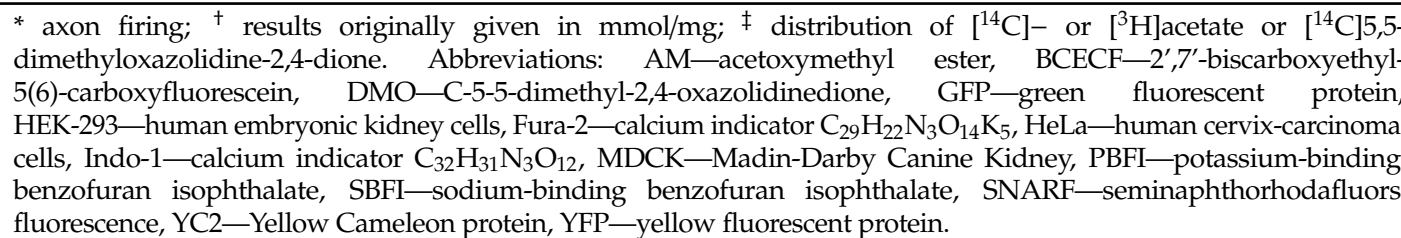 } \\
\hline
\end{tabular}


As presented in Figure 1, in the ionic strengths $I>1 \mathrm{mM}$, the ideal solution assumption $\left(\gamma_{i}=1\right)$ is not valid. In strong electrolytes, $I>200 \mathrm{mM}$, the activity coefficients $\left(\gamma_{i} \neq 1\right)$ remain almost constant. In further calculations, the activity coefficients obtained for $I=0.7 \mathrm{M}$ will be used.

a)

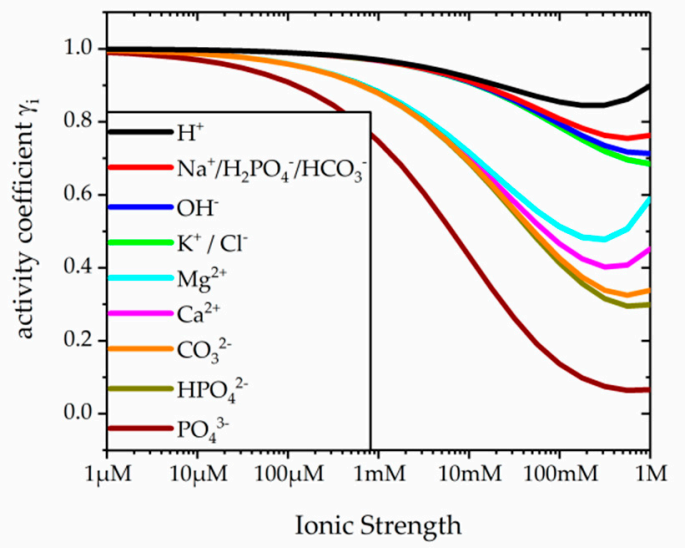

b)

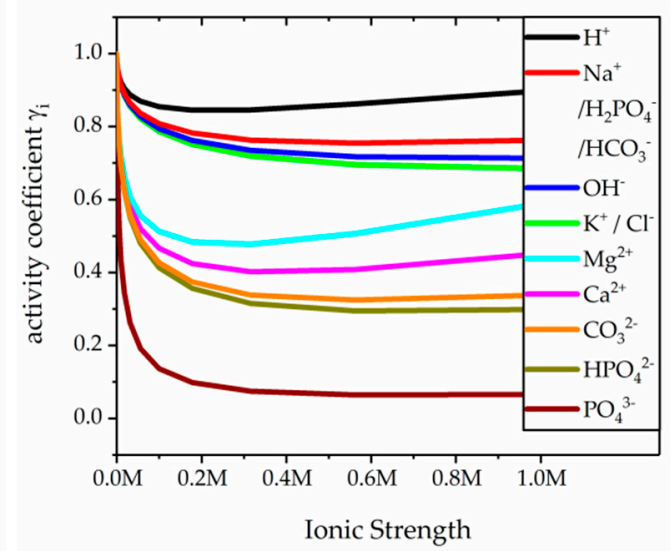

Figure 1. The calculated activity coefficients for the main inorganic ions present in mitochondria, (a) in logarithmic scale and (b) in linear scale.

\subsection{Precipitation of Carbonates}

Calcium and magnesium carbonates may form in the mitochondrial matrix due to the presence of carbon dioxide produced in citric acid cycle. Although the measurements of partial pressure of $\mathrm{CO}_{2}$ inside mitochondria is not yet possible with existing methods, it might be assumed to be equal or slightly higher than the partial pressure in blood. The partial pressure of carbon dioxide measured in human mixed venous blood is $\mathrm{pCO}_{2}=6.1 \mathrm{kPa}$ [71] to $6.3 \mathrm{kPa}$ [72]. However, during exercises, it can rise to $7.8 \mathrm{kPa}$ and after crossing the lactate acidosis threshold, it can reach values as high as $10.4 \mathrm{kPa}[72]$.

The amount of gas dissolved in a solution is proportional to its partial pressure in the gas phase [73]. The proportionality factor is called the Henry's law constant. Nevertheless, it should be kept in mind that its value still depends on certain parameters, e.g., temperature and the ionic strength of the solution. The Henry's law constant for carbon dioxide dissolved in water at $25^{\circ} \mathrm{C}$ equals $\mathrm{K}_{\mathrm{H}}=3.4 \times 10^{-4} \mathrm{~mol} \cdot \mathrm{m}^{-3} \cdot \mathrm{Pa}^{-1}$ [74]. It lowers with the increasing temperature reaching $2.5 \times 10^{-4} \mathrm{~mol} \cdot \mathrm{m}^{-3} \cdot \mathrm{Pa}^{-1}$ at $37^{\circ} \mathrm{C}[75]$.

The hydration of carbon dioxide to form carbonic acid is slow to attain equilibrium below $\mathrm{pH}=8$ in pure systems. In biological systems the hydration of carbon dioxide is catalysed by carbonic anhydrase (a Zn-containing enzyme). Only a small portion of the aqueous carbon dioxide exists in its hydrated form as $\mathrm{H}_{2} \mathrm{CO}_{3}$. Hence, the relation between the carbonic species is usually expressed as:

$$
\left\{\begin{array}{l}
\mathrm{K}_{1} \times\left\{\mathrm{CO}_{2}(\mathrm{aq})\right\}=\left\{\mathrm{H}^{+}\right\} \times\left\{\mathrm{HCO}_{3}{ }^{-}\right\} \\
\mathrm{K}_{2} \times\left\{\mathrm{HCO}_{3}{ }^{-}\right\}=\left\{\mathrm{H}^{+}\right\} \times\left\{\mathrm{CO}_{3}{ }^{2-}\right\}
\end{array}\right.
$$

where the equilibrium constants in pure water solutions at $25{ }^{\circ} \mathrm{C}$ equal $\mathrm{K}_{1}=4.5 \times 10^{-7}$, $\mathrm{K}_{2}=4.7 \times 10^{-11}[76]$.

These constants are temperature-dependent. Several different empirical equations have been developed to describe the relation between the equilibrium constants and temperature, including ones determined by Harned and co-workers [77-79], Ryzhenko [80], Millero and co-workers [81-83], as well as Plummer and Busenberg [75]. The values calculated using the latter at $37^{\circ} \mathrm{C}$, i.e., $\mathrm{K}_{1}=4.96 \times 10^{-7}$ and $\mathrm{K}_{2}=5.73 \times 10^{-11}$ are used in this work.

It should be noted, that mentioned equations are valid only for the solutions of carbon dioxide in pure water. The presence of other ions in the system lead to the increase of $\mathrm{K}_{1}$ and $\mathrm{K}_{2}$, e.g., values of 
equilibrium constants measured in sea water at $40^{\circ} \mathrm{C}$ can reach $\mathrm{K}_{1}=2.1 \times 10^{-6}$ and $\mathrm{K}_{2}=2.3 \times 10^{-10}$ [83], comparing with calculated $\mathrm{K}_{1}=5.1 \times 10^{-7}$ and $\mathrm{K}_{2}=6.0 \times 10^{-11}$. In biological systems they can vary significantly and are treated not as true thermodynamic constants, but rather as apparent dissociation constants determined experimentally from the measurements of $\mathrm{pH}, \mathrm{pCO}_{2}$ and dissolved $\mathrm{CO}_{2}$ [84]. Several studies [85-89] revealed the variability of $\mathrm{K}_{1}$ in human plasma in the range of $4.78 \times 10^{-7}$ to $1.58 \times 10^{-6}$. A case study of a diabetic child in ketoacidosis showed a change of $K_{1}$ from $3.24 \times 10^{-6}$ to $9.54 \times 10^{-7}$ after just $7 \mathrm{~h}$ of treatment [90].

\subsubsection{Calcium Carbonates}

$\mathrm{Ca}^{2+}$ and $\mathrm{CO}_{3}{ }^{2-}$ ions form calcium carbonates $\mathrm{CaCO}_{3}$. There are six different forms of $\mathrm{CaCO}_{3}$, namely:

(1) calcite, anhydrous $\mathrm{CaCO}_{3}$ with trigonal structure

(2) aragonite, anhydrous $\mathrm{CaCO}_{3}$ with orthorhombic structure

(3) vaterite, anhydrous $\mathrm{CaCO}_{3}$ with hexagonal structure

(4) monohydrocalcite, $\mathrm{CaCO}_{3} \cdot \mathrm{H}_{2} \mathrm{O}$ with trigonal structure

(5) hexahydrate known as ikaite, $\mathrm{CaCO}_{3} \cdot 6 \mathrm{H}_{2} \mathrm{O}$ with monoclinic structure

(6) amorphous calcium carbonate (ACC), colloidal hydrate containing less than one molecule of water per molecule of $\mathrm{CaCO}_{3}$.

Although the first attempts to quantify the solubility of calcium carbonates in aqueous systems date back to the middle of the $19^{\text {th }}$ century $[91,92]$ and despite the many efforts with current advanced ionic interaction models available, there are still no universally accepted values of the solubility constants of the calcium carbonate forms [93]. Values of the solubility products for various forms of $\mathrm{CaCO}_{3}$ and their activity products are presented in Table 2 . Using these values, one can calculate the equilibrium concentration of free calcium in the solutions of respective salts as functions of $\mathrm{pH}$ and partial pressure of carbon dioxide.

Table 2. The precipitation of insoluble calcium carbonates. The activity products (IAP) and the solubility products $\mathrm{K}_{\mathrm{sp}}\left(\right.$ at $\left.37^{\circ} \mathrm{C}\right)$ are obtained from the literature.

\begin{tabular}{|c|c|c|c|c|}
\hline & Formula & $\begin{array}{l}\text { Activity Product } \\
\text { (Q) }\end{array}$ & $\begin{array}{l}\text { Solubility Product, } \mathrm{K}_{\mathrm{sp}} \text { at } \\
\qquad 37^{\circ} \mathrm{C}\end{array}$ & Ref. \\
\hline Calcite & $\mathrm{CaCO}_{3}$ & $\left\{\mathrm{Ca}^{2+}\right\}\left\{\mathrm{CO}_{3}{ }^{2-}\right\}$ & $\begin{array}{c}3.31 \times 10^{-9 *} \\
3.27 \times 10^{-9} \text { to } 4.02 \times 10^{-9}\end{array}$ & {$[75]$} \\
\hline Aragonite & $\mathrm{CaCO}_{3}$ & $\left\{\mathrm{Ca}^{2+}\right\}\left\{\mathrm{CO}_{3}{ }^{2-}\right\}$ & $\begin{array}{c}4.57 \times 10^{-9 *} \\
4.67 \times 10^{-9} \text { to } 5.41 \times 10^{-9}\end{array}$ & $\begin{array}{l}{[75]} \\
{[93]}\end{array}$ \\
\hline Varietite & $\mathrm{CaCO}_{3}$ & $\left\{\mathrm{Ca}^{2+}\right\}\left\{\mathrm{CO}_{3}{ }^{2-}\right\}$ & $\begin{array}{c}1.23 \times 10^{-8 *} \\
1.18 \times 10^{-8} \text { to } 1.84 \times 10^{-8}\end{array}$ & $\begin{array}{l}{[75]} \\
{[93]}\end{array}$ \\
\hline Ikaite & $\mathrm{CaCO}_{3} \cdot 6 \mathrm{H}_{2} \mathrm{O}$ & $\left\{\mathrm{Ca}^{2+}\right\}\left\{\mathrm{CO}_{3}{ }^{2-}\right\}$ & $\begin{array}{l}2.40 \times 10^{-7 *} \\
3.50 \times 10^{-7}\end{array}$ & $\begin{array}{l}{[94]} \\
{[95]}\end{array}$ \\
\hline Monohydro-calcite & $\mathrm{CaCO}_{3} \cdot \mathrm{H}_{2} \mathrm{O}$ & $\left\{\mathrm{Ca}^{2+}\right\}\left\{\mathrm{CO}_{3}{ }^{2-}\right\}$ & $\begin{array}{l}7.09 \times 10^{-8 *} \\
2.51 \times 10^{-8}\end{array}$ & $\begin{array}{l}{[96]} \\
{[97]}\end{array}$ \\
\hline ACC & $\begin{array}{l}\mathrm{CaCO}_{3} \cdot \mathrm{nH}_{2} \mathrm{O} \\
(\mathrm{n}<1)\end{array}$ & $\left\{\mathrm{Ca}^{2+}\right\}\left\{\mathrm{CO}_{3}{ }^{2-}\right\}$ & $\begin{array}{l}9.09 \times 10^{-7 *} \\
3.98 \times 10^{-7}\end{array}$ & $\begin{array}{l}{[94]} \\
{[98]}\end{array}$ \\
\hline
\end{tabular}

* Values used in the calculations presented in this work.

\subsubsection{Magnesium Carbonates}

$\mathrm{Mg}^{2+}$ and $\mathrm{CO}_{3}{ }^{2-}$ ions can form a variety of anhydrous, hydrated and basic magnesium carbonates, namely [99-103]: 
(1) magnesite, anhydrous $\mathrm{MgCO}_{3}$ with trigonal crystal structure

(2) barringtonite, dihydrate $\mathrm{MgCO}_{3} \cdot 2 \mathrm{H}_{2} \mathrm{O}$ with triclinic structure

(3) nesquehonite, trihydrate $\mathrm{MgCO}_{3} \cdot 3 \mathrm{H}_{2} \mathrm{O}$ with monoclinic structure

(4) lansfordite, pentahydrate $\mathrm{MgCO}_{3} \cdot 5 \mathrm{H}_{2} \mathrm{O}$ with monoclinic structure

(5) pokrovskite, basic carbonate $\mathrm{Mg}_{2} \mathrm{CO}_{3}(\mathrm{OH})_{2}$ with monoclinic structure

(6) artinite, hydrated basic carbonate $\mathrm{Mg}_{2} \mathrm{CO}_{3}(\mathrm{OH})_{2} \cdot 3 \mathrm{H}_{2} \mathrm{O}$ with monoclinic structure

(7) hydromagnesite, hydrated basic carbonate $\mathrm{Mg}_{5}\left(\mathrm{CO}_{3}\right)_{4}(\mathrm{OH})_{2} \cdot 4 \mathrm{H}_{2} \mathrm{O}$ with monoclinic structure

(8) dypingite, hydrated basic carbonate $\mathrm{Mg}_{5}\left(\mathrm{CO}_{3}\right)_{4}(\mathrm{OH})_{2} \cdot 5 \mathrm{H}_{2} \mathrm{O}$ with monoclinic structure

(9) giorgiosite, hydrated basic carbonate $\mathrm{Mg}_{5}\left(\mathrm{CO}_{3}\right)_{4}(\mathrm{OH})_{2} \cdot 6 \mathrm{H}_{2} \mathrm{O}$

(10) octahydrate (UM1973-06-CO:MgH) with the formula $\mathrm{Mg}_{5}\left(\mathrm{CO}_{3}\right)_{4}(\mathrm{OH})_{2} \cdot 8 \mathrm{H}_{2} \mathrm{O}$, possibly identical to dypingite, but differs in optical properties

(11) protomagnesite, hydrated basic carbonate $\mathrm{Mg}_{5}\left(\mathrm{CO}_{3}\right)_{4}(\mathrm{OH})_{2} \cdot 11 \mathrm{H}_{2} \mathrm{O}$

(12) shelkovite, hydrated basic carbonate $\mathrm{Mg}_{7}\left(\mathrm{CO}_{3}\right)_{5}(\mathrm{OH})_{4} \cdot 24 \mathrm{H}_{2} \mathrm{O}$

Not all of the salts listed above can be precipitated directly from water solutions. Barringtonite is formed as the result of cold meteoric water percolating through olivine basalt and leaching magnesium from it [104]. Artinite is found along with hydromagnesite and other minerals as a low-temperature alteration product, as veinlets or crusts in serpentinized ultrabasic rocks [103]. Pokrovskite occurs within ultramafic bodies of dunite or serpentinite [105], and can be formed as an intermediate product in the thermal decomposition of artinite [106]. Shelkovite is a substance of anthropogenic origin, i.e., a product of burning coal mine dump [103].

Formation of the most stable anhydrous magnesite $\left(\mathrm{MgCO}_{3}\right)$ is strongly kinetically inhibited because of the high hydration energy of $\mathrm{Mg}^{2+}[107,108]$. The precipitation of magnesite is apparently inhibited at temperatures of less than $80{ }^{\circ} \mathrm{C}$ [109-111]. Therefore, various hydrous magnesium carbonates form instead. In water solutions, landsfordite, nesquehonite and hydromagnesite can precipitate, depending on the temperature. Lansfordite decomposes into nesquehonite at temperatures above $10^{\circ} \mathrm{C}[112,113]$. Most commonly, only the mineral nesquehonite can be precipitated from aqueous solutions at $25^{\circ} \mathrm{C}$ and partial pressure of $\mathrm{CO}_{2}$ close to the ambient pressure or below [100,112-116]. At higher temperatures, i.e., above approximately $40{ }^{\circ} \mathrm{C}$, various basic $\mathrm{Mg}$-carbonates are usually formed by precipitation, mostly in the form of hydromagnesite [112,114,116,117].

The transformation from nesquehonite to hydromagnesite is unlikely to follow a single simple sequential reaction pathway [107] and a range of intermediate phases may form during this transformation [99]. Giorgiosite is a very poorly described basic magnesium carbonate [103,125] and it is considered as a metastable phase between nesquehonite and hydromagnesite [103]. Protohydromagnesite, a phase similar to dypingite, appears only as a metastable intermediate phase $[114,126]$. One intermediate phase is of particular interest, namely dypingite, a mineral that is known to be produced by cyanobacteria from alkaline wetlands [127]. Octahydrate $\mathrm{Mg}_{5}\left(\mathrm{CO}_{3}\right)_{4}(\mathrm{OH})_{2} \cdot 8 \mathrm{H}_{2} \mathrm{O}$ is often considered a form of dypingite [120].

The reactions leading to the formation of the relevant magnesium carbonates together with the values of respective solubility products at $25^{\circ} \mathrm{C}$ are summarized in Table 3 . Several values obtained at $35^{\circ} \mathrm{C}$ are also included in Table 3 . Using these values, one can calculate the equilibrium concentration of free magnesium in the solutions of respective salts as functions of $\mathrm{pH}$ and partial pressure of carbon dioxide. 
Table 3. The precipitation of insoluble magnesium carbonates. The activity products $(Q)$ and the solubility products $\mathrm{K}_{\mathrm{sp}}\left(\right.$ at $\left.25^{\circ} \mathrm{C}\right)$ are obtained from the literature.

\begin{tabular}{|c|c|c|c|c|}
\hline & Formula & Activity Product $(Q)$ & $\begin{array}{l}\text { Solubility Product, } K_{\text {sp }} \text { at } 25 \\
{ }^{\circ} \mathrm{C}\end{array}$ & Ref. \\
\hline Nesquehonite & $\mathrm{MgCO}_{3} \cdot 3 \mathrm{H}_{2} \mathrm{O}$ & $\left\{\mathrm{Mg}^{2+}\right\}\left\{\mathrm{CO}_{3}{ }^{2-}\right\}$ & $\begin{array}{c}2.38 \times 10^{-6} \\
1.10 \times 10^{-5} \\
2.57 \times 10^{-6} \\
5.37 \times 10^{-6} \\
4.57 \times 10^{-6 *+} \\
5.90 \times 10^{-5}\end{array}$ & $\begin{array}{l}{[99]} \\
{[118]} \\
{[119]} \\
{[120]} \\
{[120]} \\
{[121]}\end{array}$ \\
\hline Artinite & $\mathrm{Mg}_{2} \mathrm{CO}_{3}(\mathrm{OH})_{2} \cdot 3 \mathrm{H}_{2} \mathrm{O}$ & $\left\{\mathrm{Mg}^{2+}\right\}^{2}\left\{\mathrm{CO}_{3}{ }^{2-}\right\}\left\{\mathrm{OH}^{-}\right\}^{2}$ & $\begin{array}{c}6.31 \times 10^{-18} \\
7.76 \times 10^{-18 *}\end{array}$ & $\begin{array}{l}{[119]} \\
{[122]}\end{array}$ \\
\hline Hydromagnesite & $\mathrm{Mg}_{5}\left(\mathrm{CO}_{3}\right)_{4}(\mathrm{OH})_{2} \cdot 4 \mathrm{H}_{2} \mathrm{O}$ & $\left\{\mathrm{Mg}^{2+}\right\}^{5}\left\{\mathrm{CO}_{3}{ }^{2-}\right\}^{4}\left\{\mathrm{OH}^{-}\right\}^{2}$ & $\begin{array}{c}6.31 \times 10^{-31} \\
1.25 \times 10^{-32} \\
3.16 \times 10^{-33 * \dagger} \\
8.32 \times 10^{-38}\end{array}$ & $\begin{array}{l}{[119]} \\
{[123]} \\
{[123]} \\
{[124]}\end{array}$ \\
\hline Dypingite & $\begin{array}{c}\mathrm{Mg}_{5}\left(\mathrm{CO}_{3}\right)_{4}(\mathrm{OH})_{2} \cdot \mathrm{nH}_{2} \mathrm{O} \\
(\mathrm{n}=5 \text { or } 8)\end{array}$ & $\left\{\mathrm{Mg}^{2+}\right\}^{5}\left\{\mathrm{CO}_{3}^{2-}\right\}^{4}\left\{\mathrm{OH}^{-}\right\}^{2}$ & $\begin{array}{c}1.12 \times 10^{-35} \\
9.12 \times 10^{-37 * \dagger}\end{array}$ & $\begin{array}{l}{[120]} \\
{[120]}\end{array}$ \\
\hline
\end{tabular}

* Values used in the calculations presented in this work; ${ }^{+} \mathrm{K}_{\mathrm{sp}}$ obtained at $35^{\circ} \mathrm{C}$.

\subsection{Precipitation of Orthophosphates}

Orthophosphate salts containing the $\mathrm{PO}_{4}{ }^{3-}$ group are distinguished from metaphosphates and pyrophosphates that contain $\mathrm{PO}_{3}{ }^{-}$and $\mathrm{P}_{2} \mathrm{O}_{7}{ }^{4-}$ groups, respectively. The $\mathrm{PO}_{4}{ }^{3-}$ group takes part in ATP synthesis and occurs inside the mitochondrion in relatively high concentrations. Hence, the formation of metaphosphates and pyrophosphates will not be taken into consideration.

The concentration of phosphate ions is kept constant by the phosphate carrier while the relationship between them is given as:

$$
\left\{\begin{array}{l}
\mathrm{K}_{1} \times\left\{\mathrm{H}_{3} \mathrm{PO}_{4}\right\}=\left\{\mathrm{H}^{+}\right\} \times\left\{\mathrm{H}_{2} \mathrm{PO}_{4}{ }^{-}\right\} \\
\mathrm{K}_{2} \times\left\{\mathrm{H}_{2} \mathrm{PO}_{4}{ }^{-}\right\}=\left\{\mathrm{H}^{+}\right\} \times\left\{\mathrm{HPO}_{4}{ }^{2-}\right\} \\
\mathrm{K}_{3} \times\left\{\mathrm{HPO}_{4}{ }^{2-}\right\}=\left\{\mathrm{H}^{+}\right\} \times\left\{\mathrm{PO}_{4}{ }^{3-}\right\}
\end{array}\right.
$$

where $\mathrm{K}_{1}=7.41 \times 10^{-3}, \mathrm{~K}_{2}=6.31 \times 10^{-8}$ and $\mathrm{K}_{3}=4.07 \times 10^{-13}$ [128].

\subsubsection{Calcium Orthophosphates}

The calcium ortophosphates found in nature include [30,129-131]:

(1) monocalcium phosphate monohydrate (MCPM), $\mathrm{Ca}\left(\mathrm{H}_{2} \mathrm{PO}_{4}\right)_{2} \cdot \mathrm{H}_{2} \mathrm{O}$ with $\mathrm{Ca} / \mathrm{P}$ ratio $=0.5$

(2) anhydrous monocalcium phosphate $(\mathrm{AMCP}), \mathrm{Ca}\left(\mathrm{H}_{2} \mathrm{PO}_{4}\right)_{2}$ with $\mathrm{Ca} / \mathrm{P}$ ratio $=0.5$

(3) dicalcium phosphate dihydrate, $\mathrm{CaHPO}_{4} \cdot \mathrm{H}_{2} \mathrm{O}$, known as brushite (BRU), $\mathrm{Ca} / \mathrm{P}$ ratio $=1.0$

(4) anhydrous dicalcium phosphate, $\mathrm{CaHPO}_{4}$, known as monetite, $\mathrm{Ca} / \mathrm{P}$ ratio $=1.0$

(5) octacalcium phosphate (OCP) with the formula $\mathrm{Ca}_{8}\left(\mathrm{HPO}_{4}\right)_{2}\left(\mathrm{PO}_{4}\right)_{4} \cdot 5 \mathrm{H}_{2} \mathrm{O}, \mathrm{Ca} / \mathrm{P}$ ratio $=1.33$

(6) $\alpha$-tricalcium phosphate $(\alpha-\mathrm{TCP}), \mathrm{Ca}_{3}\left(\mathrm{PO}_{4}\right)_{2}$ with monoclinic crystallographic structure and $\mathrm{Ca} / \mathrm{P}$ ratio $=1.5$

(7) $\beta$-tricalcium phosphate $(\beta-\mathrm{TCP}), \mathrm{Ca}_{3}\left(\mathrm{PO}_{4}\right)_{2}$ with rhombohedral crystallographic structure and $\mathrm{Ca} / \mathrm{P}$ ratio $=1.5$

(8) amorphous calcium phosphates (ACP), $\mathrm{Ca}_{x} \mathrm{H}_{\mathrm{y}}\left(\mathrm{PO}_{4}\right)_{\mathrm{z}} \cdot \mathrm{nH}_{2} \mathrm{O}, \mathrm{n}=3$ to $4.5, \mathrm{Ca} / \mathrm{P}$ ratio $=1.2$ to 2.2

(9) calcium-deficient hydroxyapatite $(\mathrm{CDHA}), \mathrm{Ca}_{10-\mathrm{x}}\left(\mathrm{HPO}_{4}\right)_{\mathrm{x}}\left(\mathrm{PO}_{4}\right)_{6-\mathrm{x}}(\mathrm{OH})_{2-\mathrm{x}}(0<\mathrm{x} \leq 2)$ with $\mathrm{Ca} / \mathrm{P}$ ratio $=1.5$ to 1.67

(10) hydroxyapatite (HA) with the formula $\mathrm{Ca}_{10}\left(\mathrm{PO}_{4}\right)_{6}(\mathrm{OH})_{2}, \mathrm{Ca} / \mathrm{P}$ ratio $=1.67$

(11) chloroapatite $(\mathrm{ClA})$ with the formula $\mathrm{Ca}_{10}\left(\mathrm{PO}_{4}\right)_{6}(\mathrm{Cl})_{2}, \mathrm{Ca} / \mathrm{P}$ ratio $=1.67$

(12) carbonated apatite $\left(\mathrm{CO}_{3} \mathrm{~A}\right), \mathrm{Ca}_{10}\left(\mathrm{PO}_{4}\right)_{6} \mathrm{CO}_{3}$, known as dahllite, $\mathrm{Ca} / \mathrm{P}$ ratio $=1.67$ 
(13) fluoroapatite (FA), with the formula $\mathrm{Ca}_{10}\left(\mathrm{PO}_{4}\right)_{6} \mathrm{~F}_{2}$ and $\mathrm{Ca} / \mathrm{P}$ ratio $=1.67$

(14) oxyapatite $(\mathrm{OA})$, with the formula $\mathrm{Ca}_{10}\left(\mathrm{PO}_{4}\right)_{6} \mathrm{O}$ and $\mathrm{Ca} / \mathrm{P}$ ratio $=1.67$

(15) tetracalcium phosphate (TetCP), $\mathrm{Ca}_{4}\left(\mathrm{PO}_{4}\right)_{2} \mathrm{O}$, known as hilgenstockite, $\mathrm{Ca} / \mathrm{P}$ ratio $=2.0$

Another calcium salt, i.e., isoclasite with the formula $\mathrm{Ca}_{2}\left(\mathrm{PO}_{4}\right) \mathrm{OH} \cdot 2 \mathrm{H}_{2} \mathrm{O}$, has been reported in 1870 by Sandberger [132] as orthorhombic crystals. His measurement was rather inaccurate (the angle between prismatic faces measured by contact goniometer) and the crystals could be hexagonal, possibly of apatite. Doubts concerning validity of data on isoclasite are supported by the absence of any additional description of isoclasite anywhere [133].

Some of the calcium salts mentioned above, including tetracalcium phosphate, oxyapatite, $\alpha$-tricalcium phosphate and $\beta$-tricalcium phosphate, cannot be precipitated from aqueous solutions [131]. Anhydrous monocalcium phosphate and anhydrous dicalcium phosphate are stable only in temperatures above $100{ }^{\circ} \mathrm{C}$, while monocalcium phosphate monohydrate is stable only at $\mathrm{pH}<2$ [131]. Energy dispersive $\mathrm{x}$-ray spectra from mitochondrial precipitates do not show the presence of fluor [27]. Hence, the formation of fluoroapatite can be ruled out as well.

The formulas of the calcium phosphates that might precipitate in the mitochondrion matrix, together with the values of respective solubility products at $37^{\circ} \mathrm{C}$ are summarized in Table 4 (some of the literature values have been recalculated to correspond to the activity product given in the table). To calculate the equilibrium concentration of chloroapatite and carbonated apatite, the concentrations of chlorides and carbonates have to be provided. The free chloride concentration in the mitochondrial matrix equals $\left[\mathrm{Cl}^{-}\right]=4.2 \mathrm{mM}[69]$. The concentration of carbonate ions $\left[\mathrm{CO}_{3}{ }^{2-}\right]$ are calculated using Equation (4), assuming that partial pressure of carbon dioxide equals $\mathrm{pCO}_{2}=7 \mathrm{kPa}$.

Table 4. The precipitation of insoluble calcium orthophosphates. The activity products $(Q)$ and the solubility products $\mathrm{K}_{\mathrm{sp}}\left(\right.$ at $\left.37^{\circ} \mathrm{C}\right)$ are obtained from the literature.

\begin{tabular}{|c|c|c|c|c|}
\hline & Formula & Activity Product $(Q)$ & Solubility Product, $\mathrm{K}_{\mathrm{sp}}$ at $37^{\circ} \mathrm{C}$ & Ref. \\
\hline BRU & $\mathrm{CaHPO}_{4}$ & $\left\{\mathrm{Ca}^{2+}\right\}\left\{\mathrm{HPO}_{4}{ }^{2-}\right\}$ & $\begin{array}{c}2.34 \times 10^{-7 *} \\
2.26 \times 10^{-7} \\
0.92 \times 10^{-7}\end{array}$ & $\begin{array}{l}{[129]} \\
{[134]} \\
{[135]}\end{array}$ \\
\hline $\mathrm{OCP}$ & $\mathrm{Ca}_{8}\left(\mathrm{HPO}_{4}\right)_{2}\left(\mathrm{PO}_{4}\right)_{4}$ & $\left\{\mathrm{Ca}^{2+}\right\}^{8}\left\{\mathrm{H}^{+}\right\}^{2}\left\{\mathrm{PO}_{4}{ }^{3-}\right\}^{6}$ & $\begin{array}{l}1.25 \times 10^{-96 *} \\
1.20 \times 10^{-97} \\
3.98 \times 10^{-98} \\
2.51 \times 10^{-99}\end{array}$ & $\begin{array}{l}{[129]} \\
{[134]} \\
{[136]} \\
{[137]}\end{array}$ \\
\hline $\mathrm{ACP}$ & $\mathrm{Ca}_{\mathrm{x}} \mathrm{H}_{\mathrm{y}}\left(\mathrm{PO}_{4}\right)_{\mathrm{z}}$ & $\begin{array}{c}\left\{\mathrm{Ca}^{2+}\right\}^{\mathrm{x}}\left\{\mathrm{H}^{+}\right\}^{\mathrm{y}}\left\{\mathrm{PO}_{4}{ }^{3-}\right\}^{\mathrm{z}} \\
\left\{\mathrm{Ca}^{2+}\right\}^{3}\left\{\mathrm{PO}_{4}{ }^{3-}\right\}^{2} \\
\left\{\mathrm{Ca}^{2+}\right\}\left\{\mathrm{H}^{+}\right\}^{0.22}\left\{\mathrm{PO}_{4}{ }^{3-}\right\}^{0.74}\end{array}$ & $\begin{array}{c}2.0 \times 10^{-26 * \dagger} \\
2.0 \times 10^{-33}-1.6 \times 10^{-25} \\
2.3 \times 10^{-11}, 3.2 \times 10^{-12 \S}\end{array}$ & $\begin{array}{c}{[130]} \\
{[29]} \\
{[138]}\end{array}$ \\
\hline CDHA & $\mathrm{Ca}_{10-\mathrm{x}}\left(\mathrm{HPO}_{4}\right)_{\mathrm{x}}\left(\mathrm{PO}_{4}\right)_{6-\mathrm{x}}(\mathrm{OH})_{2-\mathrm{x}}$ & $\left\{\mathrm{Ca}^{2+}\right\}^{10-x}\left\{\mathrm{H}^{+}\right\}^{\mathrm{x}}\left\{\mathrm{PO}_{4}{ }^{3-}\right\}^{6}\left\{\mathrm{OH}^{-}\right\}^{2-\mathrm{x}}$ & $\sim 7.94 \times 10^{-86 *}$ & [130] \\
\hline HA & $\mathrm{Ca}_{10}\left(\mathrm{PO}_{4}\right)_{6}(\mathrm{OH})_{2}$ & $\left\{\mathrm{Ca}^{2+}\right\}^{10}\left\{\mathrm{PO}_{4}{ }^{3-}\right\}^{6}\left\{\mathrm{OH}^{-}\right\}^{2}$ & $\begin{array}{c}1.00 \times 10^{-118} \\
6.31 \times 10^{-118 *} \\
2.00 \times 10^{-119} \ddagger \\
2.51 \times 10^{-111} \\
5.42 \times 10^{-119}\end{array}$ & $\begin{array}{c}{[29]} \\
{[129]} \\
{[139]} \\
{[140]} \\
{[141]}\end{array}$ \\
\hline $\mathrm{ClA}$ & $\mathrm{Ca}_{10}\left(\mathrm{PO}_{4}\right)_{6} \mathrm{Cl}_{2}$ & $\left\{\mathrm{Ca}^{2+}\right\}^{10}\left\{\mathrm{PO}_{4}{ }^{3-}\right\}^{6}\left\{\mathrm{Cl}^{-}\right\}^{2}$ & $3.98 \times 10^{-116 *}$ & [140] \\
\hline $\mathrm{CO}_{3} \mathrm{~A}$ & $\mathrm{Ca}_{10}\left(\mathrm{PO}_{4}\right)_{6} \mathrm{CO}_{3}$ & $\left\{\mathrm{Ca}^{2+}\right\}^{10}\left\{\mathrm{PO}_{4}^{3-}\right\}^{6}\left\{\mathrm{CO}_{3}{ }^{2-}\right\}$ & $1.58 \times 10^{-103 * \ddagger}$ & [139] \\
\hline
\end{tabular}

\subsubsection{Magnesium Orthophosphates}

The magnesium ortophosphates found in nature include [142]:

(1) anhydrous trimagnesium phosphate, $\mathrm{Mg}_{3}\left(\mathrm{PO}_{4}\right)_{2}$ with monoclinic crystal structure, occurs as the natural mineral farringtonite

(2) trimagnesium phosphate octahydrate, $\mathrm{Mg}_{3}\left(\mathrm{PO}_{4}\right)_{2} \cdot 8 \mathrm{H}_{2} \mathrm{O}$ with monoclinic structure, occurs as the natural mineral babierrite 
(3) trimagnesium phosphate docosahydrate, $\mathrm{Mg}_{3}\left(\mathrm{PO}_{4}\right)_{2} \cdot 22 \mathrm{H}_{2} \mathrm{O}$ with triclinic structure, occurs as the natural mineral cattiite

(4) anhydrous dimagnesium phosphate, $\mathrm{Mg}\left(\mathrm{HPO}_{4}\right)$

(5) dimagnesium phosphate monohydrate, $\mathrm{Mg}\left(\mathrm{HPO}_{4}\right) \cdot \mathrm{H}_{2} \mathrm{O}$

(6) dimagnesium phosphate trihydrate, $\mathrm{Mg}\left(\mathrm{HPO}_{4}\right) \cdot 3 \mathrm{H}_{2} \mathrm{O}$ with orthorhombic structure, occurs as the natural mineral newberyite

(7) dimagnesium phosphate heptahydrate, $\mathrm{Mg}\left(\mathrm{HPO}_{4}\right) \cdot 7 \mathrm{H}_{2} \mathrm{O}$ with monoclinic structure, occurs as the natural mineral phosphorrösslerite

(8) anhydrous monomagnesium phosphate, $\mathrm{Mg}\left(\mathrm{H}_{2} \mathrm{PO}_{4}\right)_{2}$

(9) monomagnesium phosphate dihydrate, $\mathrm{Mg}\left(\mathrm{H}_{2} \mathrm{PO}_{4}\right)_{2} \cdot 2 \mathrm{H}_{2} \mathrm{O}$

(10) monomagnesium phosphate tetrahydrate, $\mathrm{Mg}\left(\mathrm{H}_{2} \mathrm{PO}_{4}\right)_{2} \cdot 4 \mathrm{H}_{2} \mathrm{O}$

(11) magnesium hydroxyphosphate, $\mathrm{Mg}_{2}\left(\mathrm{PO}_{4}\right)(\mathrm{OH})$ with trigonal structure, occurs as the natural mineral holtedahlite

(12) magnesium ammonium phosphate, $\mathrm{NH}_{4} \mathrm{MgPO}_{4} \cdot 6 \mathrm{H}_{2} \mathrm{O}$ with orthorhombic structure, occurs as the natural mineral struvite

(13) magnesium potassium phosphate, $\mathrm{KMgPO}_{4} \cdot 6 \mathrm{H}_{2} \mathrm{O}$

Due to the high hydration energy, the direct precipitation of anhydrous magnesium phosphates is not possible. The anhydrous $\mathrm{Mg}\left(\mathrm{HPO}_{4}\right)$ compound is formed by dehydration at $100-170{ }^{\circ} \mathrm{C}$ [142]. The anhydrous farringtonite is formed by heating its hydrates at $400{ }^{\circ} \mathrm{C}[142]$.

Monomagnesium phosphate and its hydrates dissolve in water, forming phosphoric acid and depositing a solid precipitate of $\mathrm{Mg}\left(\mathrm{HPO}_{4}\right) \cdot 3 \mathrm{H}_{2} \mathrm{O}$ [142], e.g., precipitation monomagnesium phosphate tetrahydrate requires a non-aqueous solvent in which $\mathrm{H}_{3} \mathrm{PO}_{4}$ is soluble but $\mathrm{Mg}\left(\mathrm{H}_{2} \mathrm{PO}_{4}\right)_{2} \cdot 4 \mathrm{H}_{2} \mathrm{O}$ has limited solubility [143]. Among dimagnesium phosphates only the trihydrate is stable in the $\mathrm{MgO} / \mathrm{H}_{2} \mathrm{O} / \mathrm{P}_{2} \mathrm{O}_{5}$ system at room temperature [142]. The trimagnesium phosphate docosahydrate is metastable and reverts to octahydrate in water [144].

It has been shown that increased levels of ammonia disturb mitochondrial function, induce oxidative stress, causes mitochondrial membrane potential collapse and negatively affects several key enzymes responsible for energy metabolism [145-148]. Although the mitochondria are responsible for the production of $\mathrm{NH}_{4}{ }^{+}$ions during the oxidation of glutamate [149], in healthy mitochondria the concentration of ammonia is very low. Hence, the formation of struvite can be ruled out. Furthermore, in the biological precipitation of struvite, $\mathrm{Ca}^{2+}$ ions make struvite precipitation difficult and even inhibit it $[150,151]$.

The reactions leading to the formation of the relevant magnesium phosphates together with the values of respective solubility products at $38^{\circ} \mathrm{C}$ are summarized in Table 5 . Using these values, the equilibrium concentration of phosphates $\left[\sum \mathrm{P}_{\mathrm{i}}\right]_{\mathrm{eq}}$, required for the formation of each magnesium orthophosphate can be calculated.

Table 5. The precipitation of insoluble magnesium phosphates. The activity products $(Q)$ and the solubility products $\mathrm{K}_{\mathrm{sp}}\left(\right.$ at $\left.38^{\circ} \mathrm{C}\right)$ are obtained from the literature.

\begin{tabular}{|c|c|c|c|c|}
\hline & Formula & Activity Product $(Q)$ & Solubility Product, $\mathrm{K}_{\mathrm{sp}}$ at $38^{\circ} \mathrm{C}$ & Ref. \\
\hline Babierrite & $\mathrm{Mg}_{3}\left(\mathrm{PO}_{4}\right)_{2} \cdot 8 \mathrm{H}_{2} \mathrm{O}$ & $\left\{\mathrm{Mg}^{2+}\right\}^{3}\left\{\mathrm{PO}_{4}{ }^{3-}\right\}^{2}$ & $\begin{array}{c}6.31 \times 10^{-28} \\
5.37 \times 10^{-26 * t \ddagger} \\
2.00 \times 10^{-26 \S} \\
\end{array}$ & $\begin{array}{l}{[152]} \\
{[144]} \\
{[153]}\end{array}$ \\
\hline Newberyite & $\mathrm{Mg}\left(\mathrm{HPO}_{4}\right) \cdot 3 \mathrm{H}_{2} \mathrm{O}$ & $\left\{\mathrm{Mg}^{2+}\right\}\left\{\mathrm{HPO}_{4}{ }^{2-}\right\}$ & $\begin{array}{c}3.47 \times 10^{-5} \\
1.78 \times 10^{-6 *} \\
2.40 \times 10^{-6 \ddagger} \\
1.78 \times 10^{-6 \S} \\
1.48 \times 10^{-6 \S}\end{array}$ & $\begin{array}{l}{[154]} \\
{[144]} \\
{[144]} \\
{[155]} \\
{[153]}\end{array}$ \\
\hline Magnesium potassium phosphate & $\mathrm{KMgPO}_{4} \cdot 6 \mathrm{H}_{2} \mathrm{O}$ & $\left\{\mathrm{K}^{+}\right\}\left\{\mathrm{Mg}^{2+}\right\}\left\{\mathrm{PO}_{4}{ }^{3-}\right\}$ & $2.4 \times 10^{-11 \S}$ & [156] \\
\hline
\end{tabular}




\subsection{Precipitation of Polyphosphates}

It has been reported that $\mathrm{PO}_{4}{ }^{3-}$ can be concentrated and stored by biochemical polymerization into polyphosphate (polyP) ions [157]. They are negatively charged polyanions $\left(\mathrm{P}_{n} \mathrm{O}_{3 n+1}\right)^{(\mathrm{n}+2)-}$ with great affinity for calcium and other multivalent cations [158]. PolyP is a macroergic compound so that the energy of phosphoanhydride bond hydrolysis is the same as in ATP [159]. Polyphosphates have been found in all organisms ranging from bacteria to mammals [160].

The synthesis of polyP is mainly realized by the polyphosphate kinase, which catalyses the reaction ATP $+\left[\mathrm{PO}_{3}{ }^{-}\right]_{\mathrm{n}} \leftrightarrow \mathrm{ADP}+\left[\mathrm{PO}_{3}{ }^{-}\right]_{\mathrm{n}+1}$. PolyP can play a role in the energetic metabolism of mitochondria [161], e.g., it has been shown that, in human cell lines, specific reduction of mitochondrial polyP under expression of yeast exopolyphosphatase PPX1 significantly modulates mitochondrial bioenergetics and transport [159]. Polyphosphates (including pyrophosphate) have also a significant role in the regulation of the intensity of several biosynthetic processes in mitochondrial and cell energy metabolism [162,163].

PolyP can form several insoluble salts. Bobtelsky and Kertes [164], have analysed the properties of pyrophosphates $\left(\mathrm{P}_{2} \mathrm{O}_{7}\right)^{4-}$ and tripolyphosphates $\left(\mathrm{P}_{3} \mathrm{O}_{10}\right)^{5-}$ and the precipitation of calcium, magnesium, barium and strontium salts of these ions. With the addition of calcium to the respective polyP solution, the insoluble $\mathrm{Ca}_{2} \mathrm{P}_{2} \mathrm{O}_{7}$ and $\mathrm{Ca}_{5}\left(\mathrm{P}_{3} \mathrm{O}_{10}\right)_{2}$ will form, while the addition of magnesium leads to the precipitation of $\mathrm{Na}_{2} \mathrm{Mg}_{3}\left(\mathrm{P}_{2} \mathrm{O}_{7}\right)_{2}$ and $\mathrm{NaMg}_{2} \mathrm{P}_{3} \mathrm{O}_{10}$, respectively. Interestingly, the redissolution of these salts will take place if the excess of the polyphosphate ions is added to the solution [164].

Polyphosphate chelation of calcium reduces the free calcium concentration [165] and produces a neutral, amorphous, $\left[\mathrm{Ca}\left(\mathrm{PO}_{3}\right)_{2}\right]_{\mathrm{n}}$ complex. Discrete granules containing calcium-polyP complexes have been observed e.g., in acidocalcisomes, the electron-dense acidic organelles that have been conserved from bacteria to humans [166]. PolyP are noted to be highly inhibitory to calcium phosphate nucleation and precipitation [167], e.g., they inhibit crystalline calcium hydroxyapatite nucleation and growth from solution [168]. However, in basic $\mathrm{pH}$ solutions calcium polyphosphate glass releases hydrated calcium and polyphosphate ions into solution and, through hydrolytic degradation of polyP, calcium polyphosphate eventually transforms into hydroxyapatite [169]. The relationships between polyphosphate chemistry and apatite biomineralization as well as the possible role of polyP in mitochondria have been discussed in detail by Omelon et al. [165,170].

The important polyP forms in living cells are specific complexes with polyhydroxybutyrate (PHB) and $\mathrm{Ca}^{2+}$, which have been found in the membranes of many organisms, including membranes of mitochondria of animal cells $[171,172]$. The PHB forms a helix with a lipophilic shell of methyl groups and polar lining of ester carbonyl oxygens surrounding a core helix of polyP with $\mathrm{Ca}^{2+}$ bridging the two polymers. These helices can form voltage-dependent, $\mathrm{Ca}^{2+}$-selective channels, or be components of ion-conducting proteins: namely, the human erythrocyte $\mathrm{Ca}^{2+}$-ATPase pump and the Streptomyces lividans potassium channel [173].

The polyP pool in mitochondria likely consists of two parts, i.e., one part localized directly in the membranes as a polyP-PHB-Ca ${ }^{2+}$ complex, and the other part present in the intermembrane space and not bound to $\mathrm{PHB}$, though its association with cations, including $\mathrm{Ca}^{2+}$, is not improbable [159]. It was determined by subfractionation of isolated mitochondria by mild osmotic treatment, that intermembrane space contained $\sim 90 \%$ of total mitochondrial polyP [174]. This suggests that polyphosphates are formed outside the mitochondrial matrix. Furthermore, the formation of calcium polyP inside the matrix seems less likely than calcium orthophosphates, because the $\mathrm{Ca} / \mathrm{P}$ ratio of this complex is less than 1 , while the mitochondrial $\mathrm{Ca} / \mathrm{P}$ ratio is between 1 and 2 .

\section{Results}

\subsection{Precipitation of Calcium Carbonates}

Using the values presented in Table 2, one can calculate the equilibrium concentration of free calcium in the solutions of respective salts as functions of $\mathrm{pH}$ and partial pressure of carbon dioxide. Such calculations are shown in Figure 2. 
a)

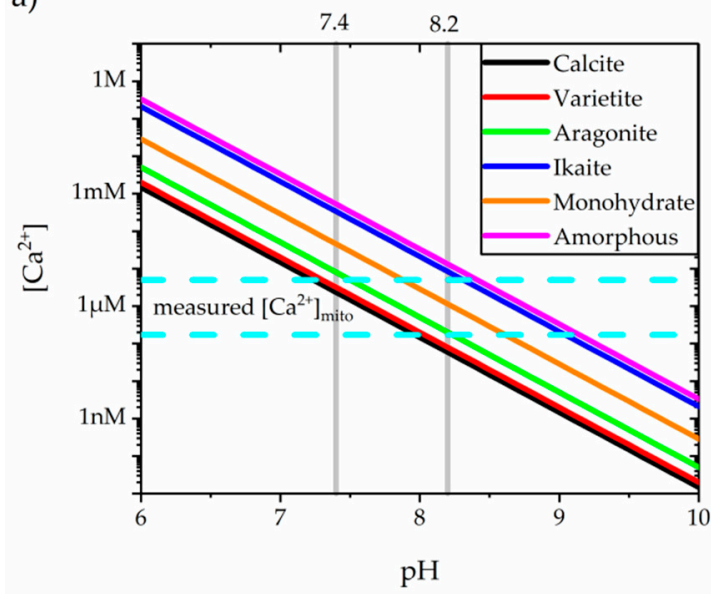

b)

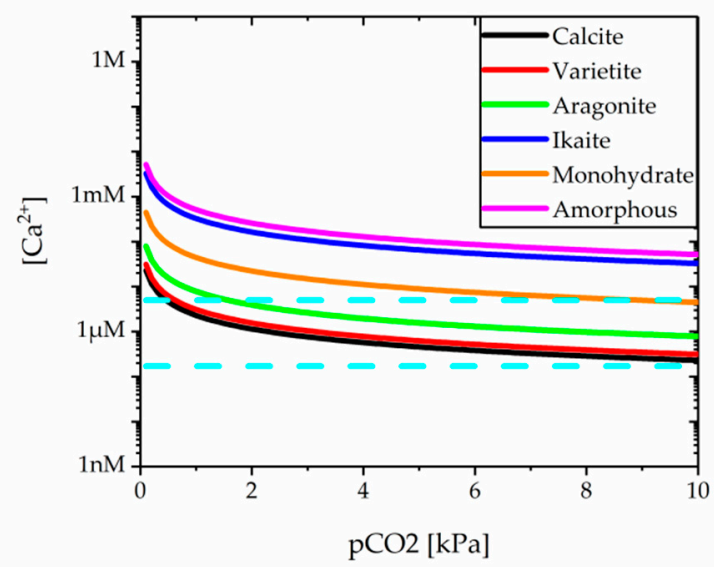

Figure 2. The calculated equilibrium concentrations of free calcium (a) as functions of $\mathrm{pH}$ at $37^{\circ} \mathrm{C}$ and $\mathrm{pCO}_{2}=7 \mathrm{kPa},(\mathbf{b})$ as a function of partial pressure of carbon dioxide at $37^{\circ} \mathrm{C}$ and $\mathrm{pH}=7.8$.

The more stable crystalline forms are generally those with a lower solubility product, hence lower equilibrium concentration of calcium. However, the formation and transformation of solid phases during the spontaneous precipitation of calcium carbonate from alkaline, carbonate-rich solutions is a highly complicated and time-dependent process. The local conditions of temperature, concentration and impurities can have a profound effect on the qualitative nature of the phases formed, as well as on the quantitative kinetics of individual processes.

The Ostwald-Lussac Law of Stages states that, in the pathway to the final crystalline state, will pass through all less stable states in order of increasing stability [175]. The formation of metastable phases is a quite common phenomenon during spontaneous precipitation of supersaturated solutions [98,176,177]. During the precipitation of more stable anhydrous forms, amorphous calcium carbonate, calcium carbonate hexahydrate and calcium monohydrocalcite appear as intermediate phases of importance and consequence. At high supersaturation, the first-formed phase is ACC, a rather unstable precursor consisting of spherical particles of calcium carbonate [94,98]. ACC changes to more stable forms via dissolution and precipitation. The solubility product of ACC is higher than for other forms of $\mathrm{CaCO}_{3}$. Hence, any solution in equilibrium with the amorphous phase will be highly supersaturated with respect to the crystalline phases, which leads to nucleation-controlled growth [178]. In other words, ACC serves as a precursor for other polymorphs, the nucleation of the polymorphous crystals occurs in the vicinity of the clouded precursor and the crystals grow by consuming the precursors surrounding the crystals [179].

If magnesium ions are present in the reaction system, they become incorporated into the ACC structure. The crystalline phase, which forms from the amorphous precursor, is controlled by the magnesium content of the precursor. Pure crystallises to vaterite [180], ACC containing $10 \% \mathrm{Mg}$ crystallises to calcite [181], ACC with 30\% crystallises to monohydrocalcite $[178,182]$ and ACC with $50 \% \mathrm{Mg}$ crystallises to protodolomite/dolomite (at temperatures higher than $60^{\circ} \mathrm{C}$ ) [183].

High concentrations of orthophosphates prevent the crystallization of the more stable anhydrous forms of $\mathrm{CaCO}_{3}$, which leads to the occurrence of ikaite and monohydrocalcite in the system $[94,98]$. Ikaite, however, for its formation requires near-freezing conditions and is unstable in the temperatures above $25^{\circ} \mathrm{C}$ [184]. Soluble acidic proteins occurring in the mitochondrial matrix might also have a strong inhibiting effect on the nucleation of anhydrous polymorphs, e.g., it has been shown that poly-L-aspartic acid completely inhibits the formation of varietite [185]. $\mathrm{Na}^{+}$and $\mathrm{Cl}^{-}$ions exert a weak or no influence on the precipitation of carbonates $[186,187]$.

The presence of both magnesium and orthophosphate ions in mitochondrial matrix suggests that monohydrocalcite might be the phase occurring inside mitochondria. However, the solubility calculations presented in Figure 2, clearly show that monohydrocalcite can form only if matrix $\mathrm{pH}$ 
is greater than $7.8\left(\right.$ for $\left.\left[\mathrm{Ca}^{2+}\right]=5 \mu \mathrm{M}\right)$ or even $8.6\left(\right.$ for $\left.\left[\mathrm{Ca}^{2+}\right]=0.17 \mu \mathrm{M}\right)$. In lower $\mathrm{pH}$, neither monohydrocalcite, nor any other calcium carbonate will precipitate.

\subsection{Precipitation of Magnesium Carbonates}

Using the solubility products presented in Table 3, one can calculate the equilibrium concentration of free magnesium in the solutions of respective salts as functions of $\mathrm{pH}$ and partial pressure of carbon dioxide. Solubility calculations, presented in Figure 3, clearly show that nesquehonite is the most stable magnesium carbonate in given conditions. It is also the only magnesium carbonate that can precipitate in the mitochondrial matrix, but only if the matrix $\mathrm{pH}$ is greater than $7.5\left(\right.$ for $\left.\left[\mathrm{Mg}^{2+}\right]=1.5 \mathrm{mM}\right)$ or even $7.9\left(\right.$ for $\left.\left[\mathrm{Mg}^{2+}\right]=0.35 \mathrm{mM}\right)$. In lower $\mathrm{pH}$, neither nesquehonite, nor any other magnesium carbonate will precipitate.

a)

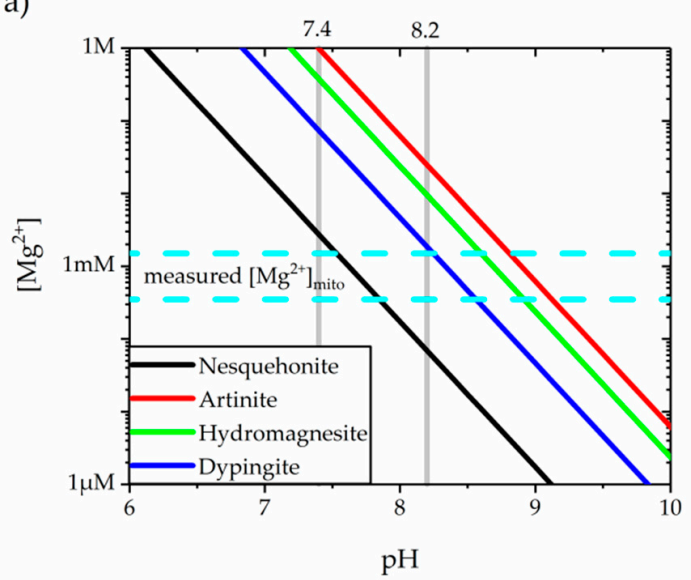

b)

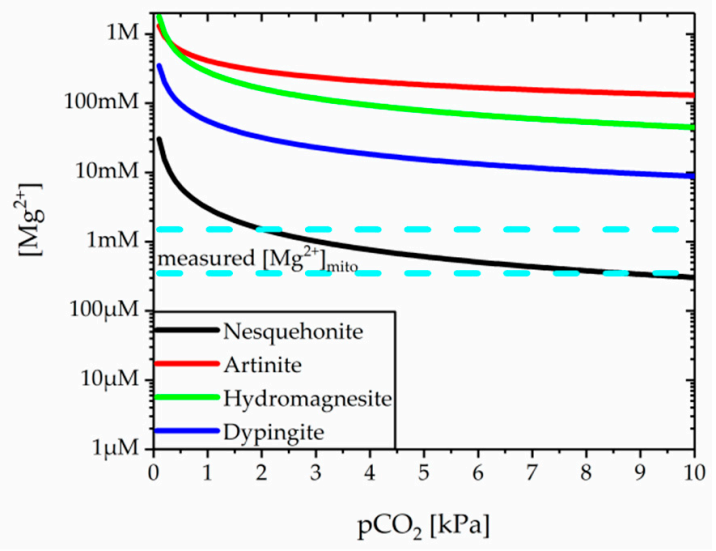

Figure 3. The calculated equilibrium concentrations of free magnesium (a) as functions of $\mathrm{pH}$ at $35^{\circ} \mathrm{C}$ and $\mathrm{pCO}_{2}=7 \mathrm{kPa},(\mathbf{b})$ as a function of partial pressure of carbon dioxide at $35^{\circ} \mathrm{C}$ and $\mathrm{pH}=7.8$.

\subsection{Precipitation of Calcium Orthophospates}

The total concentration of phosphates $\left[\sum \mathrm{P}_{\mathrm{i}}\right]_{\mathrm{eq}}$, required for the formation of each salt at constant free calcium concentration $\left[\mathrm{Ca}^{2+}\right]=0.17 \mu \mathrm{M}$ and $\left[\mathrm{Ca}^{2+}\right]=5 \mu \mathrm{M}$, is presented in Figure 4 . Salts with the lowest $\left[\sum \mathrm{P}_{\mathrm{i}}\right]_{\mathrm{eq}}$ are thermodynamically most stable and therefore dominate in the system, i.e., whenever the total concentration of free phosphates exceeds the lowest $\left[\sum P_{i}\right]_{\text {eq }}$, formation of the respective salt will occur, keeping $\left[\sum \mathrm{P}_{\mathrm{i}}\right]$ at a constant level. As shown in Figure 4, carbonated apatite is the most stable calcium salt, if $\left[\mathrm{Ca}^{2+}\right]$ is kept in the micromolar range.

Assuming the constant concentration of phosphates in the cytoplasm $\left[\sum \mathrm{P}_{\mathrm{i}}\right]_{\mathrm{cyt}}=2 \mathrm{mM}$, and that the equilibrium at phosphate translocase yields $\left[\sum \mathrm{P}_{\mathrm{i}}\right]_{\text {mat }} /\left[\sum \mathrm{P}_{\mathrm{i}}\right]_{\text {cyt }}=\left[\mathrm{H}^{+}\right]_{\mathrm{cyt}} /\left[\mathrm{H}^{+}\right]_{\text {mat }}$, one can calculate the total concentration of mitochondrial phosphates [30]. The calculated values of $\left[\sum P_{i}\right]_{\text {mat }}$ compared with the $\left[\sum \mathrm{P}_{\mathrm{i}}\right]_{\mathrm{eq}}$ of the respective salts (see Figure $4 \mathrm{~b}$ ) clearly show that if the calcium concentration is elevated, the solution of the mitochondrion matrix ( $\mathrm{pH}=7.4$ to 8.2 ) is supersaturated with respect to up to three salts. i.e., hydroxyapatite, chloroapatite and carbonated apatite. Other salts (OCP, brushite, CDHA and ACP) having $\left[\sum \mathrm{P}_{\mathrm{i}}\right]_{\mathrm{eq}}>\left[\sum \mathrm{P}_{\mathrm{i}}\right]_{\text {mat }}$ will dissolve, hence cannot form inside mitochondria.

Calcium apatites (hydroxyapatite, chloroapatite, fluoroapatite and carbonated apatite) are members of a large family of more than 75 chemically different apatites, i.e., compounds with the chemical formula: $\mathrm{A}_{2} \mathrm{~B}_{3}\left(\mathrm{XO}_{4}\right)_{3} \mathrm{Y}$, where $\mathrm{A}$ and $\mathrm{B}$ are bivalent cations, and $\mathrm{XO}_{4}$ and $\mathrm{Y}$ are trivalent and monovalent anions, respectively [188]. The high-symmetry members of the apatite family crystallise in the hexagonal system.

Calcium apatites are very often non-stoichiometric, due to the substitution of $\mathrm{OH}^{-}$in hydroxyapatite with $\mathrm{Cl}^{-}, \mathrm{F}^{-}$and $\mathrm{CO}_{3}{ }^{2-}$. Therefore, the formulas for carbonated apatite and chloroapatite are often given as $\mathrm{Ca}_{10}\left(\mathrm{PO}_{4}\right)_{6}\left(\mathrm{CO}_{3}\right)_{\mathrm{x}}(\mathrm{OH})_{2-2 \mathrm{x}}$ and $\mathrm{Ca}_{10}\left(\mathrm{PO}_{4}\right)_{6} \mathrm{Cl}_{\mathrm{x}}(\mathrm{OH})_{2-\mathrm{x}}$, respectively $[139,140]$. 
The apatite structure allows varied substitutions of calcium and phosphate ions to take place without a significant alteration in its basic structure, e.g., one of the basic phosphorite minerals, known as francolite, has a variable chemical composition, which can be represented by $(\mathrm{Ca}, \mathrm{Mg}, \mathrm{Sr}, \mathrm{Na})_{10}\left(\mathrm{PO}_{4}, \mathrm{SO}_{4}, \mathrm{CO}_{3}\right)_{6} \mathrm{~F}_{2+x}$, where $0<x<1[189,190]$.

a)

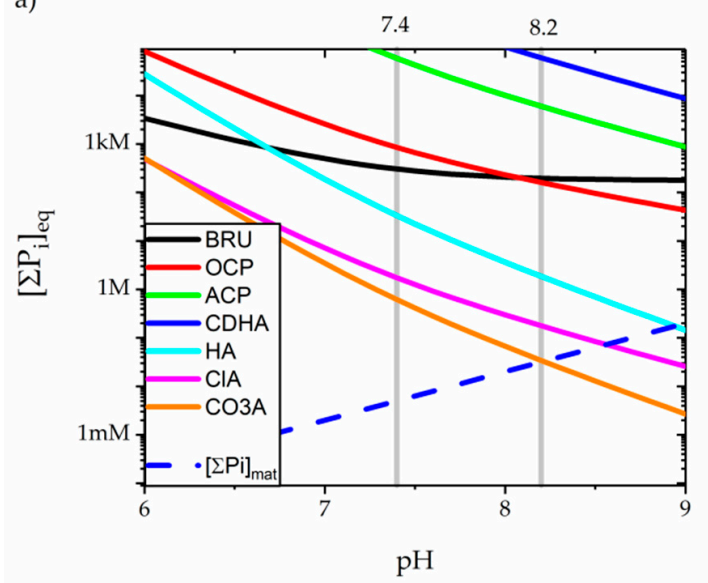

b)

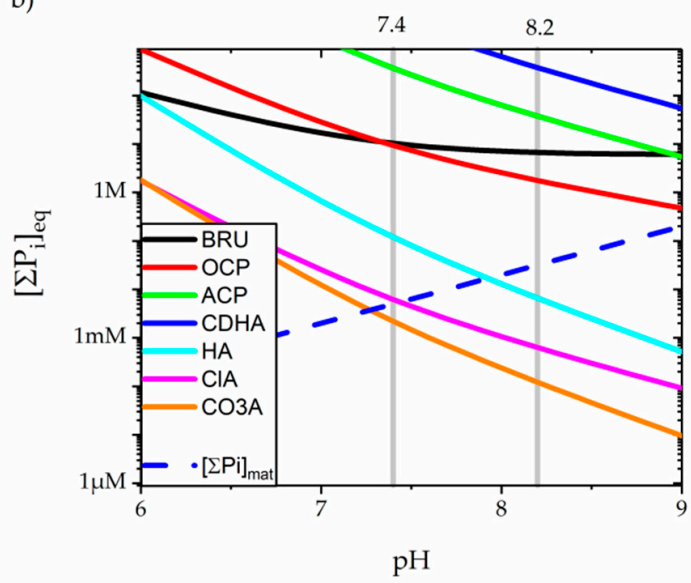

Figure 4. The calculated equilibrium concentrations $\left[\sum \mathrm{P}_{\mathrm{i}}\right]_{\text {eq }}$ required for the formation of calcium phosphates as functions of $\mathrm{pH}$. Calcium concentration set to $(\mathbf{a})\left[\mathrm{Ca}^{2+}\right]=0.17 \mu \mathrm{M}$ and $(\mathbf{b})\left[\mathrm{Ca}^{2+}\right]=5 \mu \mathrm{M}$.

Formation of $\mathrm{CO}_{3}{ }^{2-}$-substituted hydroxyapatite is common in biological and geological systems and this substitution has been well documented in several studies [191-193]. Carbonate ion in the structure of biological apatites can substitute either the $\mathrm{OH}^{-}$ion (type A carbonated apatite) or $\mathrm{PO}_{4}^{3-}$ ion (type B carbonated apatite) [194] and these two locations of carbonate species can be distinguished using spectroscopic methods $[195,196]$. The carbonate group distorts the apatite lattice and causes the resulting solid to be considerably more soluble than hydroxyapatite [197]. The substitution of carbonate for phosphate would also reduce the crystallinity and precipitation rate of HA [198]. Another specificity of biological apatites is the presence of hydrogen phosphate $\left(\mathrm{HPO}_{4}{ }^{2-}\right)$ ions in $\mathrm{PO}_{4}{ }^{3-}$ sites [199-201]. These two types of bivalent ions substituting for $\mathrm{PO}_{4}{ }^{3-}$ have been shown to correspond to the formation of calcium deficient apatites, i.e., the loss of a negative charge due to these substitutions is compensated by the creation of cationic vacancies and anionic vacancies in the $\mathrm{OH}^{-}$site [202]. The formula for biological apatites taking into account the possible existence of both type A and B substitutions reads [203,204]:

$$
\mathrm{Ca}_{10-\mathrm{x}}\left(\mathrm{PO}_{4}\right)_{6-\mathrm{x}}\left(\mathrm{HPO}_{4} \text { or } \mathrm{CO}_{3}\right)_{\mathrm{x}}\left(\mathrm{OH} \text { or } \frac{1}{2} \mathrm{CO}_{3}\right)_{2-\mathrm{x}} \text { with } 0<\mathrm{x}<2 .
$$

This general formula can be used, e.g., to represent the bone composition at all ages in many vertebrates $(x=1.7)$ or a typical composition of human tooth enamel $(x=0.6)$ [203]. The Ca/P ratio of carbonated apatite vary from $2.0\left(\mathrm{x}=2\right.$ and all type $\mathrm{B}$ substitutions with $\left.\mathrm{CO}_{3}{ }^{2-}\right)$ down to 1.2 ( $\mathrm{x}=2$ and all type $\mathrm{B}$ substitutions with $\mathrm{HPO}_{4}{ }^{2-}$ ) or even lower if cationic substitutions $\left(2 \mathrm{Na}^{+}\right.$or $\mathrm{Mg}^{2+}$ for $\mathrm{Ca}^{2+}$ ) occur.

Precipitated apatite crystals generally exhibit a structured hydrated surface layer containing mainly bivalent cations and anions. This feature should not be confused with the Stern double layer that forms on most mineral surfaces. The substitution possibilities in the hydrated layer are not well known but seem to be greater than in the core of the apatite structure [203]. Magnesium ions for example, which hardly penetrate the apatite lattice, are easily and reversibly incorporated into the hydrated layer in large amounts [205]. Ion substitutions in the hydrated layer considerably modify its structure even though these alterations seem reversible in most cases [206]. 


\subsection{Precipitation of Magnesium Orthophospates}

The solubility calculations for magnesium orthophosphates at low magnesium concentration $\left[\mathrm{Mg}^{2+}\right]=0.35 \mathrm{mM}$ (see Figure 5a) clearly show that solution of mitochondrial matrix is undersatured with the respect to all magnesium phosphate salts. Hence, they cannot precipitate. At high magnesium concentrations $\left[\mathrm{Mg}^{2+}\right]=1.5 \mathrm{mM}$, the precipitation of babierrite is possible if $\mathrm{pH}>7.9$ (see Figure $5 \mathrm{~b}$ ). In lower $\mathrm{pH}$, neither babierrite, nor any other magnesium phosphate will precipitate.

a)

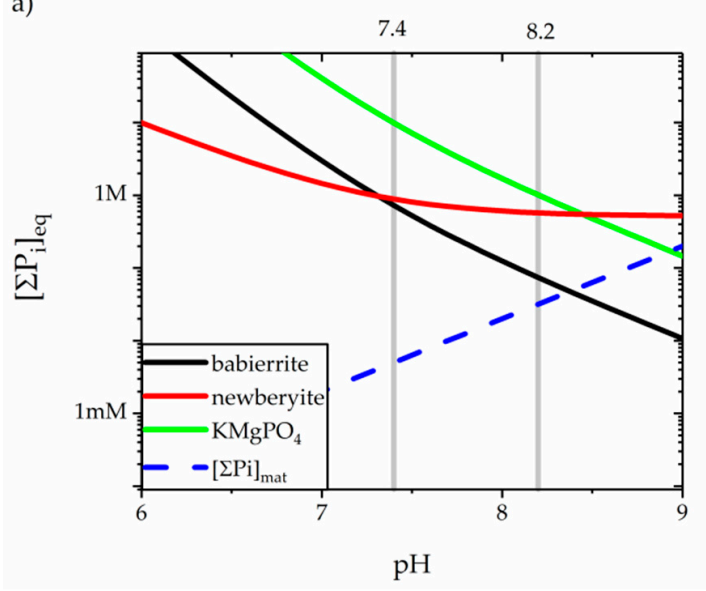

b)

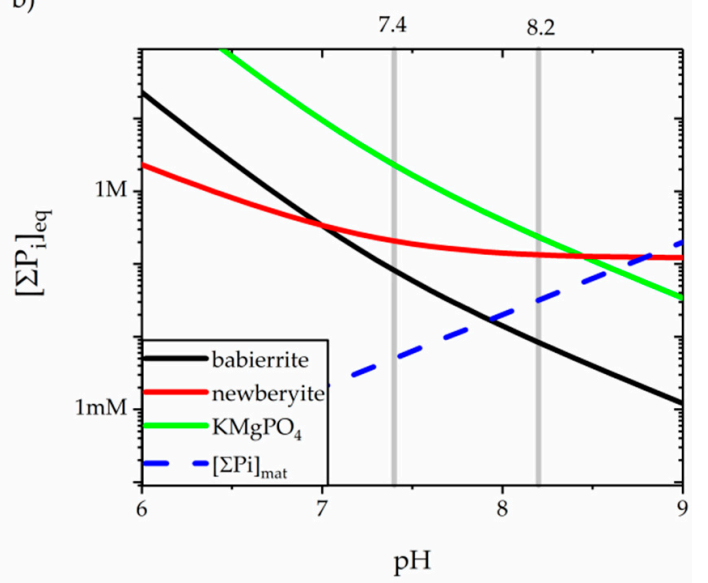

Figure 5. The calculated equilibrium concentrations $\left[\sum \mathrm{P}_{\mathrm{i}}\right]_{\mathrm{eq}}$ required for the formation of magnesium phosphates as functions of $\mathrm{pH}$. Magnesium concentration set to (a) $\left[\mathrm{Mg}^{2+}\right]=0.35 \mathrm{mM}$ and (b) $\left[\mathrm{Mg}^{2+}\right]=1.5 \mathrm{mM}$.

\section{Discussion}

The results of solubility calculations (presented in Figures 2-5) show that four different salts can form in the mitochondrion, depending on the changes in ionic concentrations induced by the metabolic processes in mitochondria and by the concentration changes in cytosol. Babierrite can precipitate at high magnesium concentration and $\mathrm{pH}>9$. Nesquehonite precipitates at $\mathrm{pH}>7.5$ (or $\mathrm{pH}>7.8$ if calcium concentration is low). Monohydrocalcite precipitates at high $\mathrm{Ca}^{2+}$ concentrations and $\mathrm{pH}>7.8$. Carbonated apatite at high calcium concentrations precipitates in a whole mitochondrial $\mathrm{pH}$ range, and dissolves when mitochondrial $\left[\mathrm{Ca}^{2+}\right]$ is low. However, these calculations do not take into account the influence of magnesium ions on precipitation of calcium salts and vice versa. They also neglect the influence of phosphate ions on the precipitation of carbonate salts and the influence of carbonate ions on the precipitation of phosphate salts. These relations are discussed below.

\subsection{Carbonates in the $\mathrm{Ca} / \mathrm{Mg}$ System}

Insoluble salts containing both calcium and magnesium are known as dolomites, i.e., the family of non-stoichiometric compounds with the formula $\mathrm{Ca}_{1-x} \mathrm{Mg}_{1+x}\left(\mathrm{CO}_{3}\right)_{2}$ [207-210]. Sedimentary dolomites with $\mathrm{x}<0$ are named calcium dolomites, and the ones with $\mathrm{x}>0$ are named magnesian dolomites. The carbonate dominated by calcite is called limestone and the mineral $\mathrm{Ca}_{0.5} \mathrm{Mg}_{1.5}\left(\mathrm{CO}_{3}\right)_{2}$ $(\mathrm{x}=0.5)$ is named huntite. Other carbonates: ankerite $\mathrm{Ca}(\mathrm{Fe}, \mathrm{Mg}, \mathrm{Mn})\left(\mathrm{CO}_{3}\right)_{2}$ and kutnohorite $\mathrm{Ca}(\mathrm{Mn}, \mathrm{Mg}, \mathrm{Fe})\left(\mathrm{CO}_{3}\right)_{2}$, with bivalent cations: $\mathrm{Fe}^{2+}$ and $\mathrm{Mn}^{2+}$, substituting a part of $\mathrm{Mg}^{2+}$ ions in the layered structure, also enter the dolomite group [211].

The hydration shell of magnesium is more strongly bound than the hydration shell of calcium [108,212]. Hence, the energy required to desolvate magnesium is higher than that of calcium. That explains the high temperatures required to crystallize anhydrous Mg-Ca carbonates, i.e., temperature of $60^{\circ} \mathrm{C}$ is required for the formation of dolomite [183] and repeated trials to precipitate it under laboratory conditions at room temperature were unsuccessful $[213,214]$. Another anhydrous 
carbonate with two cations, namely eitelite with the formula $\mathrm{Na}_{2} \mathrm{Mg}\left(\mathrm{CO}_{3}\right)_{2}$, can also be precipitated only at temperatures above $60^{\circ} \mathrm{C}$ [215].

The hydrated nature of monohydrocalcite means that full dehydration of $\mathrm{Mg}^{2+}$ is not required before incorporation into the crystal lattice. Therefore, it will more likely form than the anhydrous calcium carbonate phases [178]. Monohydrocalcite has a high capacity to accommodate magnesium within its structure. The coordination number of $\mathrm{Ca}^{2+}$ in monohydrocalcite is $8[216,217]$ and $\mathrm{Mg}^{2+}$ does not take a coordination number other than 6 . Therefore, $\mathrm{Mg}^{2+}$ is not incorporated into the monohydrocalcite structure, directly but forms discrete hydrated magnesium carbonate insertions. According to the solubility calculations presented in Figures 2 and 3, the solution in mitochondrial matrix is saturated with respect to both monohydrocalcite and nesquehonite, if $\mathrm{pH}>8$. It is in agreement with the observations of Nishiyama et al. [182], who have shown that in $\mathrm{Ca}^{2+} / \mathrm{Mg}^{2+} / \mathrm{CO}_{3}{ }^{2-}$ systems nesquehonite with very low crystallinity is expected to be formed with monohydrocalcite and the amorphous material. The hydrous magnesium carbonates surrounding monohydrocalcite play a protective role in preventing its dehydration to anhydrous calcium carbonates.

High-Mg monohydrocalcite consists of individual nanometer-sized crystals $(<35 \mathrm{~nm})$ with a significant part of its structural $\mathrm{H}_{2} \mathrm{O}$ being associated with magnesium [178]. X-ray diffraction (XRD) experiments show that monohydrocalcite exhibits low crystallinity and small particle size when the ratio of magnesium to calcium in the solid is higher than 0.4, i.e., the increase of magnesium content lead to broad X-ray diffraction peaks with low intensity. Monohydrocalcite with $\mathrm{Mg} / \mathrm{Ca}$ ratio higher than 0.5 exhibits the properties characteristic for amorphous material (no XRD peaks are observed) [182]. This corresponds well with the results of the electron microscopy measurements of brain and liver mitochondria that show a lack of crystal structures in the matrix [27]. The value of solubility of amorphous Mg-rich monohydrocalcite is slightly higher than in the case of pure monohydrocalcite [182]. Hence, in order to precipitate, it requires the solution to be more alkaline than the mitochondrial matrix.

\subsection{Carbonated Apatite in Physiological Solutions}

The studies on slow spontaneous precipitation of calcium carbonates and calcium phosphates under physiological conditions [218], show that calcium carbonate precipitation is prevented by the presence of phosphate ions at concentrations too low for the precipitation of calcium phosphate. Such precipitation is prevented, when the phosphate/bicarbonate concentration ratio is higher than about $1 / 300$. Above this ratio, the competition of the phosphate ions with the carbonate ions is sufficient to inhibit the nucleation and crystal growth of calcium carbonates, while the phosphate concentration is still too low for the nucleation of phosphates [218]. Pyrophosphate and hexametaphosphate ions inhibit the precipitation of calcium carbonate in a similar way. Hence, the composition of most biological fluids does not allow the deposition of calcium carbonate and it is suggested that such deposition can occur only under the influence of metabolic processes which locally raise the bicarbonate and lower the phosphate concentration [218].

Carbonate ions may affect the solubility of phosphate salts in several ways [191]. Ion pair complexes between calcium and bicarbonate and carbonate will form and the presence of ion pairs and reduction of free $\mathrm{Ca}^{2+}$ would increase the soluble concentration of phosphate. However, the calculations indicate that ion pairs will be the predominant calcium-containing species at $\mathrm{pH}$ greater than 8.5 and at high carbonate levels $(0.05 \mathrm{M})$ [219]. The carbonate ions may also compete with phosphate for sites on the growing crystallites. Nucleation and crystal growth may be hindered by the extra time and energy required to eliminate carbonate from phosphate sites and vice versa. When crystal growth does take place, carbonate can readily substitute for phosphate in the apatite lattice, as discussed earlier. Chemical analyses reveal that the apatitic tissues always contain smaller or larger amounts of carbonate which does not crystallize separately as carbonate [197].

Precipitation of babierrite is also inhibited, because of the presence of carbonate and calcium ions. Due to the chemical similarity between $\mathrm{Mg}^{2+}$ and $\mathrm{Ca}^{2+}$, magnesium co-precipitates with 
calcium phosphates instead, inducing the formation of an amorphous phase rather than a stable crystalline carbonated apatite [191,220]. Magnesium ions stabilize the amorphous precipitates of calcium carbonate phosphate. Apatitic precipitates are more poorly-crystallized when formed in the presence of magnesium ions than when formed in their absence, and the crystallinity of the precipitates formed in the presence of magnesium decreases with rising $\left[\mathrm{Mg}^{2+}\right]$. The $\mathrm{Ca} / \mathrm{P}$ ratios of the amorphous precipitates are often significantly lower when formed in the presence of $\mathrm{Mg}^{2+}$ ions, and the equilibrium concentrations of calcium and phosphates are higher when the precipitates are amorphous, than when they are crystalline [221].

Biological calcium apatites show a broad range of chemical compositions but also structure. It has been shown that hydroxyapatite precipitates obtained in the conditions where $\mathrm{pH}$ is kept constant show low crystallinity [222]. In primitive organisms, calcium apatites are generally amorphous, while in more elaborated organisms, especially in vertebrates, calcium apatites can crystallise [203]. Magnesium has been shown to disturb the crystallization of calcium apatites from solution when used at concentrations sufficient to be a major competitor for calcium [223]. The growth of apatite crystals is impeded by the $\mathrm{Mg}^{2+}$ ions, because they block the active growth sites and interrupt the crystal structure [224].

Organic compounds present in the mitochondrial matrix have a similar effect on phosphate crystals formation. Namely, the nucleotide diphosphates and triphosphates, including ADP and ATP, as well as low molecular weight metabolites containing two attached ester phosphate groups such as citrate also have the ability to inhibit the crystallization of calcium phosphates and may function as in vivo mineralization inhibitors $[225,226]$. Adsorption of organic compounds on the newly-formed nuclei results in a small crystal size and could be a factor in producing less crystalline phase [198]. Although apatite is usually considered a crystallographic structure, we use the term amorphous carbonated apatite to distinguish it from the amorphous calcium phosphate with the formula $\mathrm{Ca}_{x} \mathrm{H}_{y}\left(\mathrm{PO}_{4}\right)_{z}$.

A characteristic property of apatite compounds is the ability to incorporate ions and individual molecules during its synthesis. One of the most interesting examples is the molecular oxygen, which forms inside the structure through the decomposition of unstable precursor: peroxide ions and hydrogen peroxide molecules trapped in the apatite structure [227]. Mitochondria are involved in the cell's response to oxidative stress, hence the ability of apatite to entrap $\mathrm{H}_{2} \mathrm{O}_{2}$ and convert it to $\mathrm{O}_{2}$ might have had a crucial role in the evolution of mitochondria, especially in the early stages before the ability to create enzyme glutathione peroxidase has been developed.

Apatite can incorporate a large variety of foreign ions, including sodium, potassium, strontium, barium, manganese, zinc, iron, cobalt, nickel and even rare earth elements (see [228] for a detailed review). This property is used by a few organisms to eliminate toxic elements and survive in polluted environments, e.g., in gastropods Littorina Littorea, apatites allow the accumulation and biochemical deactivation of excess quantities of cadmium and other potentially harmful cations $[229,230]$. Small organic molecules, such as formate ions and glycine molecules, can also be incorporated in apatites [202,203]. It has been shown that amorphous granular aggregates forming in mitochondria include glycoproteins in their structure [231].

\section{Summary and Conclusions}

The solubility calculations for calcium and magnesium salts, including carbonates and phosphates, led to the identification of four salts that may form in the mitochondrial matrix: monohydrocalcite, nesquehonite, carbonated apatite and babierrite. Further analysis of inhibition properties of several inorganic and organic ions present in the mitochondrial matrix led to a conclusion, that non-stoichiometric magnesium-rich carbonated apatite precipitates in the matrix under physiological conditions.

The formation of crystalline apatites is inhibited by the presence of magnesium ions, ATP, ADP and citrates. Therefore, amorphous and low-crystalline carbonated apatite is precipitated. Low crystallinity 
of the precipitated material can be attributed to numerous ionic substitutions in the apatite structure. The general chemical formula of this salt can be expressed as:

$$
(\mathrm{Ca}, \mathrm{Mg})_{10-x}\left(\mathrm{PO}_{4}\right)_{6-x}\left(\mathrm{HPO}_{4}, \mathrm{CO}_{3}\right)_{x}\left(\mathrm{OH}, \frac{1}{2} \mathrm{CO}_{3}, \mathrm{Cl}\right)_{2-x} \text { with } 0<\mathrm{x}<2
$$

Numerous ions and molecules can also be incorporated in the structure of apatite, which leads to a further decrease of the crystallinity of precipitated material. The ability to incorporate hydrogen peroxide and decompose it to molecular oxygen might have an auxiliary role in the response to oxidative stress.

Precipitation and dissolution of carbonated apatite inside the matrix, affects the mitochondrial ionic concentrations, and therefore indirectly influences the action of several protein entities in the inner mitochondrial membrane including e.g., ATP synthase, phosphate translocase, calcium uniporter (MCU), mitoK $\mathrm{ATP}_{\text {and mitoK }}$ a channels as well as the $\mathrm{K}^{+} / \mathrm{H}^{+}, \mathrm{Na}^{+} / \mathrm{H}^{+}$and $\mathrm{Ca}^{2+} / 3 \mathrm{Na}^{+}$exchangers.

When the oxidative phosphorylation chain is active, the membrane potential on the inner mitochondrial membrane is highly negative, which causes the influx of calcium to the matrix through MCU and leads to the precipitation of carbonated apatite. The dominant forms of carbonic and phosphoric acid in the mitochondrial $\mathrm{pH}$ range are $\mathrm{HCO}_{3}{ }^{-}$and $\mathrm{HPO}_{4}{ }^{2-}$, respectively. Hence, precipitation of carbonated apatite leads to the production of protons, e.g.,:

$$
\begin{gathered}
10 \mathrm{Ca}^{2+}+\mathrm{HCO}_{3}^{-}+6 \mathrm{HPO}_{4}{ }^{2-} \rightarrow \mathrm{Ca}_{10}\left(\mathrm{PO}_{4}\right)_{6} \mathrm{CO}_{3}+7 \mathrm{H}^{+} \\
(10-\mathrm{x}) \mathrm{Ca}^{2+}+\mathrm{xHCO}_{3}{ }^{-}+(6-\mathrm{x}) \mathrm{HPO}_{4}{ }^{2-}+(2-\mathrm{x}) \mathrm{H}_{2} \mathrm{O} \leftrightarrow \\
\mathrm{Ca}_{10-\mathrm{x}}\left(\mathrm{PO}_{4}\right)_{6-\mathrm{x}}\left(\mathrm{CO}_{3}\right)_{\mathrm{x}}(\mathrm{OH})_{2-\mathrm{x}}+(8-\mathrm{x}) \mathrm{H}^{+}
\end{gathered}
$$

These protons are then pumped outside the mitochondrial matrix by the oxidative phosphorylation chain, which allows the production of ATP.

In anaerobic conditions, i.e., during hypoxia, the oxidative phosphorylation chain stops. Hypoxia can be caused e.g., by ischemia (low blood flow) or carbonate monoxide poisoning (oxygen in hemoglobin replaced by CO). There are three phases of ATP production during ischemia [232]. At first, up to 16 min ATP is produced due to glycolysis cytoplasm acidifies but there is no increase in sodium (5 mM) or calcium concentration $(140 \mathrm{nM})$ in the cytoplasm, i.e., Na-K-ATPase of the cytoplasmic membrane is fully active. In the second phase, as hypothesised by Dołowy [30], during hypoxia, the proton motive force is replaced by the calcium-motive force caused by the dissolution of calcium phosphates, efflux of calcium ions and alkalization of the matrix due to the following processes:

$$
\begin{gathered}
\mathrm{Ca}_{10}\left(\mathrm{PO}_{4}\right)_{6} \mathrm{CO}_{3}+7 \mathrm{H}_{2} \mathrm{O} \rightarrow 10 \mathrm{Ca}^{2+} \uparrow+\mathrm{CO}_{2} \uparrow+6 \mathrm{HPO}_{4}{ }^{2-}+8 \mathrm{OH}^{-} \\
\mathrm{Ca}_{10-x}\left(\mathrm{PO}_{4}\right)_{6-x}\left(\mathrm{CO}_{3}\right)_{x}(\mathrm{OH})_{2-x}+6 \mathrm{H}_{2} \mathrm{O} \rightarrow(10-\mathrm{x}) \mathrm{Ca}^{2+} \uparrow+\mathrm{xCO}_{2} \uparrow+(6-\mathrm{x}) \mathrm{HPO}_{4}{ }^{2-}+8 \mathrm{OH}^{-}
\end{gathered}
$$

where $\uparrow$ represents ions or molecules leaving the mitochondrial matrix. Phosphate ions forming due to the dissolution of carbonated apatite and lower ATP/ADP ratio are the two factors responsible for lowering the free energy of the ATP synthesis, hence allowing its production in hypoxic conditions. During the second phase which lasts up to $30 \mathrm{~min}$, sodium concentration in the cytoplasm is slowly rising to $30 \mathrm{mM}$ and calcium concentration to $500 \mathrm{nM}$ level. The mitochondrion can survive, as long as it can keep the $\mathrm{pH}$ of the matrix constant by the precipitation and dissolution of carbonated apatite. Then during the third phase, when all available salt dissolves, further influx of protons leads to the acidification of the matrix, hence lowering the proton motive force below the level necessary for ATP production. When matrix acidifies $\mathrm{Na} / \mathrm{H}$ and $\mathrm{K} / \mathrm{H}$ exchangers cannot prevent influx of osmotically active cations into the matrix and mitochondria swells. Low ATP levels in the cytoplasm lead to opening of the mitoK $\mathrm{ATP}_{\mathrm{AT}}$ channel. Upon reperfusion sharp increase in mitochondrial electric potential leads to further influx of osmotically active cations into the mitochondrial matrix and formation of the permeability transition pore $[233,234]$. 
The build-up of amorphous carbonated apatite should increase the maximum time of hypoxia that the cell can survive. It explains the increased life-time observed in the heart cells preconditioned by short increases of the calcium concentration [235,236]. Calcium preconditioning increases the cytoplasmic calcium ion concentration. Therefore $\mathrm{Ca}^{2+}$ from the cytoplasm is more rapidly transported into the matrix, which leads to the precipitation of carbonated apatite. A better understanding of the relationship between calcium storage and the mechanisms of ischemic preconditioning may lead to the development of new stroke-protective drugs.

Author Contributions: J.J.J. conceived, designed and performed all the calculations, analyzed the data, reviewed the available literature, wrote the paper, and supervised the overall research. R.F., K.D. and A.L. discussed the research. A.L. acquired funding. All authors have read and agreed to the published version of the manuscript.

Funding: National Science Centre (NCN, Poland) financial support via research grant no. 2014/15/B/ST5/02185 is acknowledged.

Conflicts of Interest: The authors declare no conflict of interest.

\section{References}

1. Santo-Domingo, J.; Demaurex, N. The renaissance of mitochondrial pH. J. Gen. Physiol. 2012, 139, 415-423. [CrossRef] [PubMed]

2. Griffiths, T.; Evans, M.C.; Meldrum, B.S. Intracellular sites of early calcium accumulation in the rat hippocampus during status epilepticus. Neurosci. Lett. 1982, 30, 329-334. [CrossRef]

3. Erecińska, M.; Silver, I.A. Relationships between ions and energy metabolism: Celebral calcium movements during ischemia and subsequent recovery. Can. J. Physiol. Pharmacol. 1992, 70, S190-S193. [CrossRef] [PubMed]

4. Zaidan, E.; Sims, N.R. The calcium content of mitochondria from brain subregions following short-term forebrain ischemia and recirculation in the rat. J. Neurochem. 1994, 63, 1812-1819. [CrossRef] [PubMed]

5. Fineman, I.; Hovda, D.A.; Smith, M.; Yoshino, A.; Becker, D.P. Concussive brain injury is associated with a prolonged accumulation of calcium: A 45Ca autoradiographic study. Brain Res. 1993, 624, 94-102. [CrossRef]

6. Nelson, D.L; Cox, M.M. Lehninger Principles of Biochemistry, 6th ed.; Freeman/Worth: New York, USA, 2012; pp. 690-748.

7. Lehninger, A.L.; Rossi, C.S.; Greenawalt, J.W. Respiration-dependent accumulation of inorganic phosphate and Ca ions by rat liver mitochondria. Biochem. Biophys. Res. Commun. 1963, 10, 444-448. [CrossRef]

8. Lehninger, A.L. Mitochondria and calcium ion transport. Biochem. J. 1970, 119, 129-138. [CrossRef] [PubMed]

9. Rossi, C.S.; Lehninger, A.L. Stoichiometric relationships between accumulation of ions by mitochondria and the energy-coupling sites in the respiratory chain. Biochem. Z. 1963, 338, 698-713.

10. Rossi, C.S.; Lehninger, A.L. Stoichiometry of respiratory stimulation, accumulation of $\mathrm{Ca}^{2+}$ and phosphate and oxidative phosphorylation in rat liver mitochondria. J. Biol. Chem. 1964, 239, 3971-3980.

11. Lehninger, A.L.; Carafoli, E.; Rossi, C.S. Energy-linked ion movements in mitochondrial systems. Adv. Enzymol. Relat. Areas Mol. Biol. 1967, 29, 259-320.

12. Brookes, P.S.; Yoon, Y.; Robotham, J.L.; Anders, M.W.; Sheu, S. Calcium, ATP, and ROS: A mitochondrial love-hate triangle. Am. J. Physiol. 2004, 287, 817-833. [CrossRef] [PubMed]

13. Clapham, D.E. Calcium signaling. Cell 2007, 131, 1047-1058. [CrossRef] [PubMed]

14. McCormack, J.G.; Denton, R.M. The role of mitochondrial $\mathrm{Ca}^{2+}$ transport and matrix $\mathrm{Ca}^{2+}$ in signal transduction in mammalian tissues. Biochim. Biophys. Acta 1990, 1018, 287-291. [CrossRef]

15. Gonzales, F.; Karnovsky, M.J. Electron microscopy of osteoblasts in healing fractures of rat bone. J. Biophys. Biochem. Cytol. 1961, 9, 299-316. [CrossRef] [PubMed]

16. Sutfin, L.V.; Holtrop, M.E.; Ogilvie, R.E. Microanalysis of individual mitochondrial granules with diameters less than 1000 angstroms. Science 1971, 174, 947-949. [CrossRef] [PubMed]

17. Martin, J.H.; Matthews, J.L. Mitochondrial granules in chondrocytes. Calcif. Tissue Res. 1969, 3, 184-193. [CrossRef]

18. Landis, W.J.; Paine, M.C.; Glimcher, M.J. Use of acrolein vapors for the anhydrous preparation of bone tissue for electron microscopy. J. Ultrastruct. Res. 1980, 70, 171-180. [CrossRef]

19. Matthews, J.L. Ultrastructure of calcifying tissues. Am. J. Anat. 1970, 129, 450-457. [CrossRef] 
20. Martin, J.H.; Matthews, J.L. Mitochondrial granules in chondrocytes, osteoblasts and osteocytes: An ultrastructural and microincineration study. Clin. Orthop. Relat. Res. 1970, 68, 273-278. [CrossRef]

21. Matthews, J.L.; Martin, J.H.; Sampson, H.W.; Kunin, A.S.; Roan, J.H. Mitochondrial granules in the normal and rachitic rat epiphysis. Calcif. Tissue Res. 1970, 5, 91-99. [CrossRef]

22. Landis, W.J.; Glimcher, M.J. Electron optical and analytical observations of rat growth plate cartilage prepared by ultracryomicrotomy: The failure to detect a mineral phase in matrix vesicles and the identification of heterodispersed particles as the initial solid phase of calcium phosphate deposited in the extracellular matrix. J. Ultrastruct. Res. 1982, 78, 227-268. [PubMed]

23. Gay, C.; Schraer, H. Frozen thin-sections of rapidly forming bone: Bone cell ultrastructure. Calcif. Tissue Res. 1975, 19, 39-49. [CrossRef]

24. Landis, W.J.; Glimcher, M.J. Electron diffraction and electron probe microanalysis of the mineral phase of bone tissue prepared by anhydrous techniques. J. Ultrastruct. Res. 1978, 63, 188-223. [CrossRef]

25. Landis, W.J.; Hauschka, B.T.; Rogerson, C.A.; Glimcher, M.J. Electron microscopic observations of bone tissue prepared by ultracryomicrotomy. J. Ultrastruct. Res. 1977, 59, 185-206. [CrossRef]

26. Nicholls, D.G.; Chalmers, S. The integration of mitochondrial calcium transport and storage. J. Bioenerg. Biomembr. 2004, 36, 277-281. [CrossRef]

27. Kristian, T.; Pivovarova, N.B.; Fiskum, G.; Andrews, S.B. Calcium-induced precipitate formation in brain mitochondria: Composition, calcium capacity, and retention. J. Neurochem. 2007, 102, 1346-1356. [CrossRef] [PubMed]

28. Thomas, R.S.; Greenawalt, J.W. Microincineration, electron microscopy, and electron diffraction of calcium phosphateloaded mitochondria. J. Cell Biol. 1968, 39, 55-76. [CrossRef]

29. Chalmers, S.; Nichols, D.G. The relationship between free and total calcium concentration in the matrix of liver and brain mitochondria. J. Biol. Chem. 2003, 278, 19062-19070. [CrossRef] [PubMed]

30. Dołowy, K. Calcium phosphate buffer formed in the mitochondrial matrix during preconditioning supports $\Delta \mathrm{pH}$ formation and ischemic ATP production and prolongs cell survival-A hypothesis. Mitochondrion 2019, 47, 210-217. [CrossRef]

31. Bal, W.; Kurowska, E.; Maret, W. The Final Frontier of $\mathrm{pH}$ and the Undiscovered Country Beyond. PLoS ONE 2012, 7, e45832. [CrossRef]

32. Bose, S.; French, S.; Evans, F.J.; Joubert, F.; Balaban, R.S. Metabolic network control of oxidative phosphorylation. Multiple roles of inorganic phosphate. J. Biol. Chem. 2003, 278, 39155-39165. [CrossRef] [PubMed]

33. Baysal, K.; Brierley, G.P.; Novgorodov, S.; Jung, D.W. Regulation of the mitochondrial $\mathrm{Na}^{+} / \mathrm{Ca}^{2+}$ antiport by matrix pH. Arch. Biochem. Biophys. 1991, 291, 383-389. [CrossRef]

34. Balut, C.; vandeVen, M.; Despa, S.; Lambrichts, I.; Ameloot, M.; Steels, P.; Smets, I. Measurement of cytosolic and mitochondrial $\mathrm{pH}$ in living cells during reversible metabolic inhibition. Kidney Int. 2008, 73, 226-232. [CrossRef] [PubMed]

35. Takahashi, A.; Zhang, Y.; Centonze, V.E.; Herman, B. Measurement of Mitochondrial pH In Situ. BioTechniques 2001, 30, 804-815. [CrossRef]

36. Abad, M.F.C.; Di Benedetto, G.; Magalhães, P.J.; Filippin, L.; Pozzan, T. Mitochondrial pH monitored by a new engineered green fluorescent protein mutant. J. Biol. Chem. 2003, 279, 11521-11529. [CrossRef]

37. Matsuyama, S.; Llopis, J.; Deveraux, Q.L.; Tsien, R.Y.; Reed, J.C. Changes in intramitochondrial and cytosolic pH: Early events that modulate caspase activation during apoptosis. Nature Cell Biol. 2000, 2, 318-325. [CrossRef]

38. Poburko, D.; Santo-Domingo, J.; Demaurex, N. Dynamic regulation of the mitochondrial proton gradient during cytosolic calcium elevations. J. Biol. Chem. 2011, 286, 11672-11684. [CrossRef]

39. Hutson, S. M. pH regulation of mitochondrial branched chain $\alpha$-keto acid transport and oxidation in rat heart mitochondria. J. Biol. Chem. 1987, 262, 9629-9635.

40. Ivannikov, M.V.; Macleod, G.T. Mitochondrial free $\mathrm{Ca}^{2+}$ levels and their effects on energy metabolism in Drosophila motor nerve terminals. Biophys. J. 2013, 104, 2353-2361. [CrossRef]

41. Al-Nassar, I.; Crompton, $\mathrm{M}$. The entrapment of the $\mathrm{Ca}^{2+}$ indicator arsenazo III in the matrix space of rat liver mitochondria by permeabilization and resealing. $\mathrm{Na}^{+}$-dependent and -independent effluxes of $\mathrm{Ca}^{2+}$ in arsenazo III-loaded mitochondria. Biochem. J. 1986, 239, 31-40. [CrossRef] 
42. Samson, E.; Lemaire, G.; Marchand, J.; Beaudoin, J.J. Modeling chemical activity effects in strong ionic solutions. Comp. Mat. Sci. 1999, 15, 285-294. [CrossRef]

43. Jung, D.W.; Davis, M.H.; Brierley, G.P. Estimation of matrix $\mathrm{pH}$ in isolated heart mitochondria using a fluorescent probe. Anal. Biochem. 1989, 178, 348-354. [CrossRef]

44. Addanki, S.; Cahill, F.D.; Sotos, J.F. Determination of intramitochondrial pH and intramitochondrialextramitochondrial $\mathrm{pH}$ gradient of isolated heart mitochondria by the use of 5,5-dimethyl-,4- oxazolidinedione. J. Biol. Chem. 1968, 243, 2337-2348. [PubMed]

45. Porcelli, A.M.; Ghelli, A.; Zanna, C.; Pinton, P.; Rizzuto, R.; Rugolo, M. pH difference across the outer mitochondrial membrane measured with a green fluorescent protein mutant. Biochem. Biophys. Res. Commun. 2005, 326, 799-804. [CrossRef] [PubMed]

46. Llopis, J.; McCaffery, J.M.; Miyawaki, A.; Farquhar, M.G.; Tsien, R.Y. Measurement of cytosolic, mitochondrial, and Golgi pH in single living cells with green fluorescent proteins. Proc. Natl. Acad. Sci. 1998, 95, 6803-6808. [CrossRef] [PubMed]

47. Greenbaum, N.L.; Wilson, D.F. Role of intramitochondrial $\mathrm{pH}$ in the energetics and regulation of mitochondrial oxidative phosphorylation. Biochim. Biophys. Acta Bioenerg. 1991, 1058, 113-120. [CrossRef]

48. Schoolwerth, A.C.; LaNoue, K.F.; Hoover, W.J. Effect of $\mathrm{pH}$ on glutamate efflux from rat kidney mitochondria. Am. J. Physiol. Renal Physiol. 1984, 246, F266-F271. [CrossRef]

49. Baron, S. Role of mitochondrial Na+ concentration, measured by CoroNa Red, in the protection of metabolically inhibited MDCK cells. J. Am. Soc. Nephrol. 2005, 16, 3490-3497. [CrossRef]

50. Jung, D.W.; Apel, L.M.; Brierley, G.P. Transmembrane gradients of free $\mathrm{Na}+$ in isolated heart mitochondria estimated using a fluorescent probe. Am. J. Physiol. 1992, 262, C1047-C1055. [CrossRef]

51. Donoso, P.; Mill, J.G.; O’Neill, S.C.; Eisner, D.A. Fluorescence measurements of cytoplasmic and mitochondrial sodium concentration in rat ventricular myocytes. J. Physiol. 1992, 448, 493-509. [CrossRef]

52. Augustynek, B.; Wrzosek, A.; Koprowski, P.; Kiełbasa, A.; Bednarczyk, P.; Łukasiak, A.; Dołowy, K.; Szewczyk, A. What we don't know about mitochondrial potassium channels? Postępy Biochemii 2016, 62, 189-198. [PubMed]

53. Zoeteweij, J.P.; van de Water, B.; de Bont, H.J.; Nagelkerke, J.F. Mitochondrial $\mathrm{K}^{+}$as modulator of $\mathrm{Ca}^{2+}$-dependent cytotoxicity in hepatocytes. Novel application of the $\mathrm{K}^{+}$-sensitive dye PBFI $\left(\mathrm{K}^{+}\right.$-binding benzofuran isophthalate) to assess free mitochondrial $\mathrm{K}^{+}$concentrations. Biochem. J. 1994, 299, 539-543. [CrossRef] [PubMed]

54. Costa, A.D.T.; Quinlan, C.L.; Andrukhiv, A.; West, I.C.; Jabůrek, M.; Garlid, K.D. The direct physiological effects of mitoKATP opening on heart mitochondria. Am. J. Physiol. Heart Circ. Physiol. 2006, 290, H406-H415. [CrossRef] [PubMed]

55. Dordick, R.S.; Brierley, G.P.; Garlid, K.D. On the mechanism of A23187-induced potassium efflux in rat liver mitochondria. J. Biol. Chem. 1980, 255, 10299-10305. [PubMed]

56. Corkey, B.E.; Duszynski, J.; Rich, T.L.; Matschinsky, B.; Williamson, J.R. Regulation of free and bound magnesium in rat hepatocyte and isolated mitochondria. J. Biol. Chem. 1986, 261, 2567-2574. [PubMed]

57. Jung, D.W.; Brierley, G.P. Matrix magnesium and the permeability of heart mitochondria to potassium ion. J. Biol. Chem. 1986, 261, 6408-6415. [PubMed]

58. Gout, E.; Rebeille, F.; Douce, R.; Bligny, R. Interplay of $\mathrm{Mg}^{2+}$, ADP, and ATP in the cytosol and mitochondria: Unravelling the role of $\mathrm{Mg}^{2+}$ in cell respiration. Proc. Natl. Acad. Sci. 2014, 111, E4560-E4567. [CrossRef]

59. Jung, D.W.; Apel, L.; Brierley, G.P. Matrix free magnesium changes with metabolic state in isolated heart mitochondria. Biochemistry 1990, 29, 4121-4128. [CrossRef]

60. Rutter, G.A.; Osbaldeston, N.J.; McCormack, J.G.; Denton, R.M. Measurement of matrix free $\mathrm{Mg}^{2+}$ concentration in rat heart mitochondria by using entrapped fluorescent probes. Biochem. J. 1990, 271, 627-634. [CrossRef]

61. Arnaudeau, S.; Kelley, W.L.; Walsh, J.V.; Demaurex, N. Mitochondria recycle $\mathrm{Ca}^{2+}$ to the endoplasmic reticulum and prevent the depletion of neighboring endoplasmic reticulum regions. J. Biol. Chem. 2001, 276, 29430-29439. [CrossRef]

62. Brandenburger, Y.; Kennedy, E.D.; Python, C.P.; Rossier, M.F.; Vallotton, M.B.; Wollheim, C.B.; Capponi, A.M. Possible role for mitochondrial calcium in angiotensin II- and potassium-stimulated steroidogenesis in bovine adrenal glomerulosa cells. Endocrinology 1996, 137, 5544-5551. [CrossRef] [PubMed] 
63. Schreur, J.H.; Figueredo, V.M.; Miyamae, M.; Shames, D.M.; Baker, A.J.; Camacho, S.A. Cytosolic and mitochondrial $\left[\mathrm{Ca}^{2+}\right]$ in whole hearts using indo-1 acetoxymethyl ester: effects of high extracellular $\mathrm{Ca}^{2+}$. Biophys. J. 1996, 70, 2571-2580. [CrossRef]

64. Miyata, H.; Silverman, H.S.; Sollott, S.J.; Lakatta, E.G.; Stern, M.D.; Hansford, R.G. Measurement of mitochondrial free $\mathrm{Ca}^{2+}$ concentration in living single rat cardiac myocytes. Am. J. Physiol. 1991, 261, H1123-H1134. [CrossRef]

65. Moreno-Sanchez, R.; Hansford, R.G. Dependence of cardiac mitochondrial pyruvate dehydrogenase activity on intramitochondrial free $\mathrm{Ca}^{2+}$ concentration. Biochem. J. 1988, 256, 403-412. [CrossRef] [PubMed]

66. Allen, S.P.; Stone, D.; McCormack, J.G. The loading of fura-2 into mitochondria in the intact perfused rat heart and its use to estimate matrix $\mathrm{Ca}^{2+}$ under various conditions. J. Mol. Cell. Cardiol. 1992, 24, 765-773. [CrossRef]

67. Lukács, G.L.; Kapus, A. Measurement of the matrix free $\mathrm{Ca}^{2+}$ concentration in heart mitochondria by entrapped fura-2 and quin2. Biochem. J. 1987, 248, 609-613. [CrossRef]

68. Davis, M.H.; Altschuld, R.A.; Jung, D.W.; Brierley, G.P. Estimation of intramitochondrial pCa and pH by fura-2 and 2,7 biscarboxyethyl-5(6)-carboxyfluorescein (BCECF) fluorescence. Biochem. Biophys. Res. Commun. 1987, 149, 40-45. [CrossRef]

69. Jahn, S.C.; Rowland-Faux, L.; Stacpoole, P.W.; James, M.O. Chloride concentrations in human hepatic cytosol and mitochondria are a function of age. Biochem. Biophys. Res. Commun. 2015, 459, 463-468. [CrossRef]

70. Kielland, J. Individual Activity Coefficients of Ions in Aqueous Solutions. J. Am. Chem. Soc. 1937, 59, 1675-1678. [CrossRef]

71. Arthurs, G.J.; Sudhakar, M. Carbon dioxide transport. Contin. Educ. Anaesth. Critical Care Pain 2005, 5, 207-210. [CrossRef]

72. Sun, X.-G.; Hansen, J.E.; Stringer, W.W.; Ting, H.; Wasserman, K. Carbon dioxide pressure-concentration relationship in arterial and mixed venous blood during exercise. J. Appl. Physiol. 2001, 90, 1798-1810. [CrossRef] [PubMed]

73. Henry, W. Experiments on the quantity of gases absorbed by water, at different temperatures, and under different pressures. Phil. Trans. R. Soc. Lond. 1803, 93, 29-274.

74. Sander, R. Compilation of Henry's law constants (version 4.0) for water as solvent. Atmos. Chem. Phys. 2015, 15, 4399-4981. [CrossRef]

75. Plummer, L.N.; Busenberg, E. The solubilities of calcite, aragonite and vaterite in $\mathrm{CO}_{2}-\mathrm{H}_{2} \mathrm{O}$ solutions between 0 and $90{ }^{\circ} \mathrm{C}$, and an evaluation of the aqueous model for the system $\mathrm{CaCO}_{3}-\mathrm{CO}_{2}-\mathrm{H}_{2} \mathrm{O}$. Geochim. Cosmochim. Acta 1982, 46, 1011-1040. [CrossRef]

76. Dąbrowska, S.; Migdalski, J.; Lewenstam, A. A Breakthrough Application of a Cross-Linked Polystyrene Anion-Exchange Membrane for a Hydrogencarbonate Ion-Selective Electrode. Sensors 2019, 19, 1268. [CrossRef]

77. Harned, H.S.; Davis, R.D., Jr. The ionization constant of carbonic acid in water and the solubility of carbon dioxide in water and aqueous salt solutions from 0 to $50^{\circ}$ C. J. Am. Chem. Soc. 1943, 65, 2030-2037. [CrossRef]

78. Harned, H.S.; Bonner, F.T. The first ionization constant of carbonic acid in aqueous solutions of sodium chloride. J. Am. Chem. Soc. 1945, 67, 1026-1031. [CrossRef]

79. Harned, H.S.; Scholes, S.R. The ionization constant of HCO3- from 0 to $50{ }^{\circ}$ C. J. Am. Chem. Soc. 1941, 63, 1706-1709. [CrossRef]

80. Ryzhenko, B.N. Determination of dissociation constants of carbonic acid and the degree of hydrolysis of the $\mathrm{CO}$ :- and $\mathrm{HCO}$; ions in solutions of alkali carbonates and bicarbonates at elevated temperatures. Geochemistry 1963, 2, 151-164.

81. Millero, F.J. The thermodynamics of the carbonate system in seawater. Geochim. Cosmochim. Acta 1979, 43, 1651-1661. [CrossRef]

82. Prieto, F.J.M.; Millero, F.J. The determination of $\mathrm{pK} 1+\mathrm{pK} 2$ in seawater as a function of temperature and salinity. Geochim. Cosmochim. Acta 2002, 66, 2529-2540.

83. Millero, F. J.; Graham, T.B.; Huang, F.; Bustos-Serrano, H.; Pierrot, D. Dissociation constants of carbonic acid in seawater as a function of salinity and temperature. Marine Chem. 2006, 100, 80-94. [CrossRef]

84. Flear, C.T.G.; Covington, A.K.; Stoddart, J.C. Bicarbonate or $\mathrm{CO}_{2}$ ? Arch. Int. Med. 1984, 144, $2285-2287$. [CrossRef] 
85. Flear, C.T.G.; Roberts, S.W.; Hayes, S.; Stoddart, J.C.; Covington, A.K. $\mathrm{pK}_{1}{ }^{\prime}$ and bicarbonate concentration in plasma. Clin. Chem. 1987, 33, 13-20. [CrossRef] [PubMed]

86. Tibi, L.; Bhattacharya, S.S.; Flear, C.T.G. Variability of $\mathrm{pK}_{1}{ }^{\prime}$ of human plasma. Clin. Chim. Acta 1982, 121, 15-31. [CrossRef]

87. Natelson, S.; Nobel, D. Effect of the variation of $\mathrm{pK}^{\prime}$ of the Henderson-Hasselbalch equation on values obtained for total $\mathrm{CO} 2$ calculated from $\mathrm{pCO} 2$ and $\mathrm{pH}$ values. Clin. Chem. 1977, 23, 767-769.

88. Masters, P.; Blackburn, M.E.C.; Henderson, M.J.; Barrett, J.F.R.; Dear, P.R.F. Determination of plasma bicarbonate of neonates in intensive care. Clin. Chem. 1988, 34, 1483-1485. [CrossRef]

89. Rosan, R.; Enlander, D.; Ellis, S. Unpredictable error in calculated bicarbonate homeostasis during pediatric intensive care: The delusion of the fixed $\mathrm{pK}^{\prime}$. Clin. Chem. 1983, 29, 69-73. [CrossRef]

90. Kost, G.J.; Trent, J.K.T.; Saeed, D. Indications for measurement of total carbon dioxide in arterial blood. Clin. Chem. 1988, 34, 1650-1652. [CrossRef]

91. Fresenius, R. Ueber die Löslichkoitsverhältnisse voneinigen bei der quantitativen Analyse als Bestimmungsformen, etc., dienenden Niederschlägen. Ann. Chem. Pharm. 1846, 59, 117-128. [CrossRef]

92. Lassaigne, J.L. Löslichkeit einiger kohlensauren Salze in kohlensaurem Wasser. Ann. Chem. Pharm. 1848, 68, 253-254.

93. De Visscher, A.; Vanderdeelen, J. Estimation of the Solubility Constant of Calcite, Aragonite, and Vaterite at $25^{\circ} \mathrm{C}$ Based on Primary Data Using the Pitzer Ion Interaction Approach. Monatshefte für Chemie 2003, 134, 769-775. [CrossRef]

94. Clarkson, J.R.; Price, T.J.; Adams, C.J. Role of metastable phases in the spontaneous precipitation of calcium carbonate. J. Chem. Sot. Faraday Trans. 1992, 88, 243-249. [CrossRef]

95. Brečević, L.; Nielsen, A.E. Solubility of Calcium Carbonate Hexahydrate. Acta Chim. Scandinav. 1993, 47, 668-673. [CrossRef]

96. Kralj, D.; Brečević, L. Dissolution kinetics and solubility of calcium carbonate monohydrate. Colloids Surf. A: Physicochem. Eng. Aspects 1995, 96, 287-293. [CrossRef]

97. Hull, H.; Turnbull, A.G. A thermochemical study of monohydrocalcite. Geochim. Cosmochim. Acta 1973, 37, 685-694. [CrossRef]

98. Brečević, L.; Nielsen, A.E. Solubility of amorphous calcium carbonate. J. Cryst. Growth 1989, 98, 504-510. [CrossRef]

99. Canterford, J.H.; Tsambourakis, G.; Lambert, B. Some observations on the properties of dypingite, $\mathrm{Mg}_{5}\left(\mathrm{CO}_{3}\right)_{4}(\mathrm{OH})_{2} \cdot 5 \mathrm{H}_{2} \mathrm{O}$, and related minerals. Mineral. Mag. 1984, 48, 437-442. [CrossRef]

100. Hänchen, M.; Prigiobbe, V.; Baciocchi, R.; Mazzotti, M. Precipitation in the Mg-carbonate system-Effects of temperature and $\mathrm{CO}_{2}$ pressure. Chem. Eng. Sci. 2008, 63, 1012-1028. [CrossRef]

101. Ropp, R.C. Encyclopedia of the Alkaline Earth Compounds, 1st ed.; Elsevier Science Ltd.: Oxford, UK, 2013; pp. 360-362.

102. Rheinheimer, V.; Unluer, C.; Liu, J.; Ruan, S.; Pan, J.; Monteiro, P. XPS Study on the Stability and Transformation of Hydrate and Carbonate Phases within MgO Systems. Materials 2017, 10, 75. [CrossRef]

103. Mineralogy Database. Available online: https://www.mindat.org/ (accessed on 4 February 2020).

104. Nashar, B. Barringtonite-A new hydrous magnesium carbonate from Barrington Tops, New South Wales, Australia. Mineral. Mag. J. Mineral. Soc. 1965, 34, 370-372. [CrossRef]

105. Fitzpatrick, J.J. Pokrovskite: Its possible relationship to mcguinnessite and the problem of excess water. In Proceedings of the 14th Meeting International Mineralogical Association, Abstracts, Stanford, CA, USA, 13-18 July 1986; p. 101.

106. Gunter, J.R.; Oswald, H.R. Crystal structure of $\mathrm{Mg} 2(\mathrm{OH}) 2(\mathrm{CO} 3)$, deduced from the topotactic thermal decomposition of artinite. J. Solid State Chem. 1977, 21, 211-215. [CrossRef]

107. Hopkinson, L.; Kristova, P.; Rutt, K.; Cressey, G. Phase transitions in the system $\mathrm{MgO}-\mathrm{CO}_{2}-\mathrm{H}_{2} \mathrm{O}$ during $\mathrm{CO}_{2}$ degassing of Mg-bearing solutions. Geochim. Cosmochim. Acta 2012, 76, 1-13. [CrossRef]

108. Di Tommaso, D.; De Leeuw, N.H. Structure and dynamics of the hydrated magnesium ion and of the solvated magnesium carbonates: Insights from first principles simulations. Phys. Chem. Chem. Phys. 2010, 12, 894-901. [CrossRef] [PubMed]

109. Saldi, G.D.; Jordan, G.; Schott, J.; Oelkers, E.H. Magnesite growth rates as a function of temperature and saturation state. Geochim. Cosmochim. Acta 2009, 73, 56465657. [CrossRef] 
110. Saldi, G.D.; Schott, J.; Pokrovsky, O.S.; Gautier, Q.; Oelkers, E.H. An experimental study of magnesite precipitation rates at neutral to alkaline conditions and $100-200{ }^{\circ} \mathrm{C}$ as a function of $\mathrm{pH}$, aqueous solution composition and chemical affinity. Geochim. Cosmochim. Acta 2012, 83, 93109. [CrossRef]

111. Sayles, F.L.; Fyfe, W.S. The crystallization of magnesite from aqueous solution. Geochim. Cosmochim. Acta 1973, 37, 87-99. [CrossRef]

112. Dell, R.; Weller, S.W. The thermal decomposition of nesquehonite $\mathrm{MgCO} 3 \cdot \mathrm{H} 2 \mathrm{O}$ and magnesium ammonium carbonate $\mathrm{MgCO}_{3} \cdot\left(\mathrm{NH}_{4}\right)_{2} \mathrm{CO}_{3} \cdot 4 \mathrm{H}_{2} \mathrm{O}$. Trans. Faraday Soc. 1959, 55, 2203-2220. [CrossRef]

113. Ming, D.W.; Franklin, W.T. Synthesis and Characterization of Lansfordite and Nesquehonite. Soil Sci. Soc. Am. J. 1985, 49, 1303-1308. [CrossRef]

114. Davies, P.J.; Bubela, B. The transformation of nesquehonite into hydromagnesite. Chem. Geol. 1973, 12, 289-300. [CrossRef]

115. Kloprogge, J.T.; Martens, W.N.; Nothdurft, L.; Duong, L.V.; Webb, G.E. Low temperature synthesis and characterization of nesquehonite. J. Mater. Sci. Lett. 2003, 22, 825-829. [CrossRef]

116. Zhang, Z.P.; Zheng, Y.J.; Ni, Y.W.; Liu, Z.M.; Chen, J.P.; Liang, X.M. Temperature- and pH-dependent morphology and FT-IR analysis of magnesium carbonate hydrates. J. Phys. Chem. B 2006, 110, 12969-12973. [CrossRef] [PubMed]

117. Fernandez, A.I.; Chimenos, J.M.; Segarra, M.; Fernandez, M.A.; Espiell, F. Procedure to obtain hydromagnesite from a MgO-containing residue. Kinetic study. Ind. Eng. Chem. Res. 2000, 39, 3653-3658. [CrossRef]

118. Kline, W. D. The solubility of magnesium carbonate (nesquehonite) in water at $25^{\circ} \mathrm{C}$ and pressures of carbon dioxide up to one atmosphere. Am. Chem. Soc. J. 1929, 51, 2093-2097. [CrossRef]

119. Langmuir, D. Stability of Carbonates in the System MgO-CO2-H2O. J. Geol. 1965, 73, 730-754. [CrossRef]

120. Harrison, A.L.; Mavromatis, V.; Oelkers, E.H.; Bénézeth, P. Solubility of the hydrated Mg-carbonates nesquehonite and dypingite from 5 to $35^{\circ} \mathrm{C}$ : Implications for $\mathrm{CO} 2$ storage and the relative stability of Mg-carbonates. Chem. Geol. 2019, 504, 123-135. [CrossRef]

121. Johnston, J. The solubility-product constant of calcium and magnesium carbonates. J. Am. Chem. Soc. 1915, 37, 2001-2020. [CrossRef]

122. Hemingway, B.S.; Robie, R.A. A calorimetric determination of the standard enthalpies of formation of huntite, $\mathrm{CaMg}\left(\mathrm{CO}_{3}\right)_{4}$, and artinite, $\mathrm{Mg}_{2}(\mathrm{OH})_{2} \mathrm{CO}_{3} \cdot 3 \mathrm{H}_{2} \mathrm{O}$, and their standard Gibbs free energies of formation. J. Res. U.S. Geol. Surv. 1972, 1, 535-541.

123. Cheng, W.; Li, Z. Controlled Supersaturation Precipitation of Hydromagnesite for the $\mathrm{MgCl}_{2}-\mathrm{Na}_{2} \mathrm{CO}_{3}$ System at Elevated Temperatures: Chemical Modeling and Experiment. Ind. Eng. Chem. Res. 2010, 49, 1964-1974. [CrossRef]

124. Gautier, Q.; Bénézeth, P.; Mavromatis, V.; Schott, J. Hydromagnesite solubility product and growth kinetics in aqueous solution from 25 to $75^{\circ} \mathrm{C}$. Geochim. Cosmochim. Acta 2014, 138, 1-20. [CrossRef]

125. Raade, G. Dypingite, a new hydrous basic carbonate of magnesium, from Norway. Am. Mineral. 1970, 55, 1457-1465.

126. Botha, A.; Strydom, C.A. Preparation of a magnesium hydroxy carbonate from magnesium hydroxide. Hydrometallurgy 2001, 62, 175-183. [CrossRef]

127. Power, I.M.; Wilson, S.A.; Thom, J.M.; Dipple, G.M.; Southam, G. Biologically induced mineralization of dypingite by cyanobacteria from an alkaline wetland near Atlin, British Columbia, Canada. Geochem. Trans. 2007, 8, 13. [CrossRef] [PubMed]

128. Larsen, M.J. An investigation of the theoretical background for the stability of the calcium-phosphate salts and their mutual conversion in aqueous solutions. Arch. Oral Biol. 1986, 31, 757-761. [CrossRef]

129. Fernández, E.; Gil, F.J.; Ginebra, M.P.; Driessens, F.C.M.; Planell, J.A.; Best, S.M. Calcium phosphate bone cements for clinical applications Part I: Solution chemistry. J. Mat. Sci. Mater. Med. 1999, 10, 169-176. [CrossRef]

130. Dorozhkin, S.V. Calcium orthophosphates. J. Mat. Sci. 2007, 42, 1061-1095. [CrossRef]

131. Dorozhkin, S.V. Calcium orthophosphates. Biomatter 2011, 1, 121-164. [CrossRef]

132. Sandberger, F. Ueber Isoklas und Kollophan, zwei neue Phosphate. J. Prakt. Chemie Neue Folge 1870, 2 , 125-130. [CrossRef]

133. Ondruš, P.; Veselovský, F.; Hloušek, J.; Skála, R.; Vavřín, I.; Frýda, J.; Čejka, J.; Gabašová, A. Secondary minerals of the Jáchymov (Joachimsthal) ore district. J. Czech Geol. Soc. 1997, 42, 3-76. 
134. Madsen, H.E.L. Ionic Concentration in Calcium Phosphate Solutions, I. Solutions Saturated with Respect to Brushite or Tetracalcium Monohydrogen Phosphate at $37^{\circ} \mathrm{C}$. Acta Chem. Scand. 1970, 24, 1671-1676. [CrossRef]

135. Sutter, J.R.; McDowell, H.; Brown, W.E. Solubility study of calcium hydrogen phosphate. Ion-pair formation. Inorg. Chem. 1971, 10, 1638-1643. [CrossRef]

136. Tung, M.S.; Eidelman, N.; Sieck, B.; Brown, W.E. Octacalcium phosphate solubility product from 4 to $37^{\circ} \mathrm{C}$. J. Res. Nat. Bur. Stand. 1988, 93, 613-624. [CrossRef]

137. Shyu, L.J.; Perrez, L.; Zawacky, S.J.; Heughebaert, J.C.; Nancollas, G.H. The Solubility of Octacalcium Phosphate at $37^{\circ} \mathrm{C}$ in the System $\mathrm{Ca}(\mathrm{OH})_{2}-\mathrm{H}_{3} \mathrm{PO}_{4}-\mathrm{KNO}_{3}-\mathrm{H}_{2} \mathrm{O}$. J. Dent. Res. 1983, 62, 398-400. [CrossRef]

138. Christoffersen, M.R.; Christoffersen, J.; Kibalczyc, W. Apparent solubilities of two amorphous calcium phosphates and of octacalcium phosphate in the temperature range $30-42{ }^{\circ} \mathrm{C}$. J. Cryst. Growth 1990, 106, 349-354. [CrossRef]

139. Ito, A.; Maekawa, K.; Tsutsumi, S.; Ikazaki, F.; Tateishi, T. Solubility product of OH-carbonated hydroxyapatite. J. Biomed. Mater. Res. 1997, 36, 522-528. [CrossRef]

140. Narasaraju, T.S.B.; Rao, K.K.; Rai, U.S. Determination of solubility products of hydroxylapatite, chlorapatite, and their solid solutions. Can. J. Chem. 1979, 57, 1919-1922. [CrossRef]

141. Moreno, E.C.; Kresak, M.; Zahradnik, R.T. Physicochemical Aspects of Fluoride-Apatite Systems Relevant to the Study of Dental Caries. Caries Res. 1977, 11, 142-171. [CrossRef]

142. Schrödter, K.; Bettermann, G.; Staffel, T.; Wahl, F.; Klein, T.; Hofmann, T. Phosphoric Acid and Phosphates. In Ullmann's Encyclopedia of Industrial Chemistry, 7th ed.; Wiley-VCH: Weinheim, Germany, 2012; Volume 26, pp. 679-712.

143. Dudenhoefer, R.; Messing, G.L.; Brown, P.W.; Johnson, G.G. Synthesis and characterization of monomagnesium phosphate tetrahydrate. J. Cryst. Growth 1992, 125, 121-126. [CrossRef]

144. Taylor, A.W.; Frazier, A.W.; Gurney, E.L.; Smith, J.P. Solubility products of di- and trimagnesium phosphates and the dissociation of magnesium phosphate solutions. Trans. Faraday Soc. 1963, 59, 1585-1589. [CrossRef]

145. Norenberg, M. Oxidative and nitrosative stress in ammonia neurotoxicity. Hepatology 2003, 37, $245-248$. [CrossRef]

146. Felipo, V.; Butterworth, R.F. Mitochondrial dysfunction in acute hyperammonemia. Neurochem. Int. 2002, 40, 487-491. [CrossRef]

147. Niknahad, H.; Jamshidzadeh, A.; Heidari, R.; Zarei, M.; Ommati, M.M. Ammonia-induced mitochondrial dysfunction and energy metabolism disturbances in isolated brain and liver mitochondria, and the effect of taurine administration: Relevance to hepatic encephalopathy treatment. Clin. Exp. Hepatol. 2017, 3, 141-151. [CrossRef] [PubMed]

148. Lai, J.C.K; Cooper, A.J.L. Neurotoxicity of ammonia and fatty acids: Differential inhibition of mitochondrial dehydrogenases by ammonia and fatty acyl coenzyme a derivatives. Neurochem. Res. 1991, 16, 795-803. [CrossRef] [PubMed]

149. Hird, F.J.R.; Marginson, M.A. Formation of Ammonia from Glutamate by Mitochondria. Nature 1964, 201, 1224-1225. [CrossRef] [PubMed]

150. Beavon, J.; Heatley, N.G. The occurrence of struvite (magnesium ammonium phosphate hexahydrate) in microbial cultures. J. Gen. Microbiol. 1962, 31, 167-169. [CrossRef] [PubMed]

151. Rivadeneyra, M.A.; Ramos-Cormenzana, A.; García-Cervigón, A. Bacterial formation of struvite. Geomicrobiol. J. 1983, 3, 151-163. [CrossRef]

152. Holt, L.E.; Pierce, J.A.; Kajdi, C.N. The solubility of the phosphates of strontium, barium, and magnesium and their relation to the problem of calcification. J. Colloid Sci. 1954, 9, 409-426. [CrossRef]

153. Racz, G.J.; Soper, R.J. Solubility of dimagnesium phosphate trihydrate and dimagnesium phosphate. Can. J. Soil Sci. 1968, 48, 265-269. [CrossRef]

154. Tabor, H.; Hastings, A.B. The ionization constant of secondary magnesium phosphate. Biol. Chem. 1943, 148, 627-632.

155. Verbeeck, R.M.H.; De Bruyne, P.A.M.; Driessens, F.C.M.; Verbeek, F. Solubility of magnesium hydrogen phosphate trihydrate and ion-pair formation in the system magnesium hydroxide-phosphoric acid-water at $25^{\circ}$ C. Inorg. Chem. 1984, 23, 1922-1926. [CrossRef]

156. Taylor, A.W.; Frazier, A.W.; Gurney, E.L. Solubility products of magnesium ammonium and magnesium potassium phosphates. Trans. Faraday Soc. 1963, 59, 1580-1584. [CrossRef] 
157. Crosby, C.H.; Bailey, J. The role of microbes in the formation of modern and ancient phosphatic mineral deposits. Front. Microbiol. 2012, 3, e241-e247. [CrossRef] [PubMed]

158. Van Wazer, J.R.; Campanella, D.A. Structure and properties of the condensed phosphates. IV. Complex ion formation in polyphosphate solutions. J. Am. Chem. Soc. 1950, 72, 655-663. [CrossRef]

159. Kulakovskaya, T.V.; Lichko, L.P.; Vagabov, V.M.; Kulaev, I.S. Inorganic polyphosphates in mitochondria. Biochemistry (Moscow) 2010, 75, 825-831. [CrossRef] [PubMed]

160. Kornberg, A.; Rao, N.N.; Ault-Riché, D. Inorganic Polyphosphate: A Molecule of Many Functions. Ann. Rev. Biochem. 1999, 68, 89-125. [CrossRef] [PubMed]

161. Beauvoit, B.; Rigoulet, M.; Guerin, B.; Canioni, P. Polyphosphates as a source of high energy phosphates in yeast mitochondria: A ${ }^{31}$ P NMR study. FEBS Lett. 1989, 252, 17-21. [CrossRef]

162. Mansurova, S. E. Inorganic pyrophosphate in mitochondrial metabolism. Biochim. Biophys. Acta (BBA) Bioenerg. 1989, 977, 237-247. [CrossRef]

163. Pavlov, E.; Aschar-Sobbi, R.; Campanella, M.; Turner, R.J.; Gómez-García, M.R.; Abramov, A.Y. Inorganic Polyphosphate and Energy Metabolism in Mammalian Cells. J. Biol. Chem. 2010, 285, 9420-9428. [CrossRef]

164. Bobtelsky, M.; Kertes, S. The polyphosphates of calcium, strontium, barium and magnesium: Their complex character, composition and behaviour. J. Appl. Chem. 1954, 4, 419-429. [CrossRef]

165. Omelon, S.; Grynpas, M. Polyphosphates affect biological apatite nucleation. Cells Tissues Organs 2011, 194, 171-175. [CrossRef]

166. Docampo, R.; de Souza, W.; Miranda, K.; Rohloff, P.; Moreno, S.N.J. Acidocalcisomes-conserved from bacteria to man. Nat. Rev. Microbiol. 2005, 3, 251-261. [CrossRef] [PubMed]

167. Fleisch, H.; Neuman, W.F. Mechanisms of calcification: Role of collagen, polyphosphates, and phosphatase. Am. J. Physiol. 1961, 200, 1296-1300. [CrossRef] [PubMed]

168. Francis, M. The inhibition of calcium hydroxyapatite crystal growth by polyphosphonates and polyphosphates. Calcif. Tissue Res. 1969, 3, 151-162. [CrossRef] [PubMed]

169. Bunker, B.C.; Arnold, G.W.; Wilder, J.A. Phosphate glass dissolution in aqueous solutions. J. Non-Cryst. Solids 1984, 64, 291-316. [CrossRef]

170. Omelon, S.; Ariganello, M.; Bonucci, E.; Grynpas, M.; Nanci, A. A Review of Phosphate Mineral Nucleation in Biology and Geobiology. Calcif. Tissue Int. 2013, 93, 382-396. [CrossRef]

171. Reusch, R. N. Poly- -hydroxybutyrate/Calcium Polyphosphate Complexes in Eukaryotic Membranes. Exp. Biol. Med. 1989, 191, 377-381. [CrossRef]

172. Pavlov, E.; Zakharian, E.; Bladen, C.; Diao, C.T.M.; Grimbly, C.; Reusch, R.N.; French, R.J. A large, voltage-dependent channel, isolated from mitochondria by water-free chloroform extraction. Biophys. J. 2005, 88, 2614-2625. [CrossRef]

173. Reusch, R. N. Transmembrane Ion Transport by Polyphosphate/Poly-(R)-3-hydroxybutyrate Complexes. Biochemistry (Moscow) 2000, 65, 280-295.

174. Vagabov, V.M.; Trilisenko, L.V.; Kulaev, I.S. Dependence of inorganic polyphosphate chain length on the orthophosphate content in the culture medium of the yeast Saccharomyces cerevisae. Biochemistry 2000, 65, 349-354.

175. Nancollas, G.H. The mechanism of precipitation of biological minerals. The phosphates, oxalates and carbonates of calcium. Croat. Chim. Acta 1983, 56, 741-752.

176. Brečevič, L.; Füredi-Milhofer, H. Precipitation of calcium phosphates from electrolyte solutions. Calcif. Tissue Res. 1972, 10, 82-90. [CrossRef] [PubMed]

177. Söhnel, O.; Mullin, J.W. Precipitation of calcium carbonate. J. Crystal Growth 1982, 60, 239-250. [CrossRef]

178. Rodriguez-Blanco, J.D.; Shaw, S.; Bots, P.; Roncal-Herrero, T.; Benning, L.G. The role of Mg in the crystallization of monohydrocalcite. Geochim. Cosmochim. Acta 2014, 127, 204-220. [CrossRef]

179. Kitamura, M. Crystallization and Transformation Mechanism of Calcium Carbonate Polymorphs and the Effect of Magnesium Ion. J. Colloid Interface Sci. 2001, 236, 318-327. [CrossRef] [PubMed]

180. Bots, P.; Benning, L.G.; Rodriguez-Blanco, J.D.; Roncal-Herrero, T.; Shaw, W. Mechanistic Insights into the Crystallization of Amorphous Calcium Carbonate (ACC). Cryst. Growth Des. 2012, 12, 3806-3814. [CrossRef]

181. Rodriguez-Blanco, J.D.; Shaw, S.; Bots, P.; Roncal-Herrero, T.; Benning, L.G. The role of $\mathrm{pH}$ and $\mathrm{Mg}$ on the stability and crystallization of amorphous calcium carbonate. J. Alloys Compd. 2012, 536, S477-S479. [CrossRef] 
182. Nishiyama, R.; Munemoto, T.; Fukushi, K. Formation condition of monohydrocalcite from $\mathrm{CaCl}_{2}-\mathrm{MgCl}_{2}-\mathrm{Na}_{2} \mathrm{CO}_{3}$ solutions. Geochim. Cosmochim. Acta 2013, 100, 217-231. [CrossRef]

183. Rodriguez-Blanco, J.D.; Shaw, S.; Benning, L.G. The realtime kinetics and mechanisms of nucleation and growth of dolomite from solution. Geochim. Cosmochim. Acta 2009, 73, A1111.

184. Bischoff, J.L.; Fitzpatrick, J.A.; Rosenbauer, R.J. The solubility and stabilization of ikaite $\left(\mathrm{CaCO}_{3} .6 \mathrm{H}_{2} \mathrm{O}\right)$ from $0^{\circ}$ to $25^{\circ}$ C. J. Geol. 1992, 101, 21-33. [CrossRef]

185. Njegić-Džakula, B.; Brečević, L.; Falini, G.; Kralj, D. Kinetic Approach to Biomineralization: Interactions of Synthetic Polypeptides with Calcium Carbonate Polymorphs. Croatica Chemica Acta 2011, 84, 301-314. [CrossRef]

186. Cailleau, P.; Dragone, D.; Girou, A.; Humbert, L.; Jacquin, C.; Roques, H. Etude expérimentale de la précipitation des carbonates de calcium en présence de l'ion magnesium. Bull. Soc. Fran. Mineral. Crystallogr. 1977, 100, 81-88. [CrossRef]

187. Rivadeneyra, M.A.; Delgado, R.; Quesada, E.; Ramos-Cormenzana, A. Precipitation of calcium carbonate by Deleya halophila in media containing $\mathrm{NaCl}$ as sole salt. Curr. Microbiol. 1991, 22, 185-190. [CrossRef]

188. White, T.J.; Dong, Z.L. Structural derivation and crystal chemistry of apatite. Acta Cryst. B 2003, 59, 1-16. [CrossRef] [PubMed]

189. McArthur, J.M. Francolite geochemistry-compositional controls during formation, diagenesis, metamorphism and weathering. Geochim. Cosmochim. Acta 1985, 49, 23-35. [CrossRef]

190. Benmore, R.A.; Coleman, M.L.; McArthur, J.M. Origin of is sedimentary francolite from its sulphur and carbon isotope composition. Nature 1983, 302, 516-518. [CrossRef]

191. Ferguson, J.F.; McCarty, P.L. Effects of carbonate and magnesium on calcium phosphate precipitation. Environ. Sci. Technol. 1971, 5, 534-540. [CrossRef]

192. Van der Houwen, J.A.M.; Cressey, G.; Cressey, B.A.; Valsami-Jones, E. The effect of organic ligands on the crystallinity of calcium phosphate. J. Cryst. Growth 2003, 249, 572-583. [CrossRef]

193. Suchanek, W.J.; Byrappa, K.; Shuk, P.; Riman, R.E.; Janas, V.F.; Tenhuisen, K.S. Mechanochemical-hydrothermal synthesis of calcium phosphate powders with coupled magnesium and carbonate substitution. J. Solid State Chem. 2004, 17, 793-799. [CrossRef]

194. Fleet, M.E.; Liu, X. Coupled substitution of type A and B carbonate in sodium-bearing apatite. Biomaterials 2007, 28, 916-926. [CrossRef]

195. LeGeros, R.Z.; Trautz, O.R.; Klein, E.; LeGeros, J.P. Two types of carbonate substitution in the apatite structure. Experientia 1969, 25, 5-7. [CrossRef]

196. Rey, C.; Collins, B.; Goehl, T.; Dickson, R.I.; Glimcher, M.J. The carbonate environment in bone mineral: A resolution-enhanced fourier transform infrared spectroscopy study. Calcif. Tissue Int. 1989, 45, 157-164. [CrossRef] [PubMed]

197. Trautz, O.R. Crystallographic studies of calcium carbonate phosphate. Ann. N. Y. Acad. Sci. 1960, 85, 145-160. [CrossRef] [PubMed]

198. Cao, X.; Harris, W.G.; Josan, M.S.; Nair, V.D. Inhibition of calcium phosphate precipitation under environmentally-relevant conditions. Sci. Total Environ. 2007, 383, 205-215. [CrossRef]

199. Legros, R.; Balmain, N.; Bonel, G. Age-related changes in mineral of rat and bovine cortical bone. Calcif. Tissue Int. 1987, 41, 137-144. [CrossRef]

200. Wu, Y.; Glimcher, M.J.; Rey, C.; Ackerman, J.L. A unique protonated phosphate group in bone mineral not present in synthetic calcium phosphates. Identification by phosphorus-31 solid state NMR spectroscopy. J. Mol. Biol. 1994, 244, 423-435. [CrossRef]

201. Rey, C.; Shimizu, M.; Collins, B.; Glimcher, M.J. Resolution-enhanced Fourier transform infrared spectroscopy study of the environment of phosphate ions in the early deposits of a solid phase of calcium phosphate in bone and enamel, and their evolution with age. I: Investigations in the $v_{4} \mathrm{PO}_{4}$ domain. Calcif. Tissue Int. 1990, 46, 384-394. [CrossRef]

202. Montel, G.; Bonel, G.; Heughebaert, J.C.; Trombe, J.C.; Rey, C. New concepts in the composition, crystallization and growth of the mineral component of calcified tissues. J. Cryst. Growth 1981, 53, 74-99. [CrossRef]

203. Rey, C.; Combes, C.; Drouet, C.; Sfihi, H. Chemical Diversity of Apatites. Adv. Sci. Tech. 2006, 49, 27-36. [CrossRef]

204. Combes, C.; Cazalbou, S.; Rey, C. Apatite Biominerals. Minerals 2016, 6, 34. [CrossRef] 
205. Cazalbou, S.; Eichert, D.; Ranz, X.; Drouet, C.; Combes, C.; Harmand, M.F.; Rey, C. Ion exchanges in apatites for biomedical application. J. Mater. Sci. Mater. Med. 2005, 16, 405-409. [CrossRef]

206. Eichert, D.; Combes, C.; Drouet, C.; Rey, C. Formation and evolution of hydrated surface layers of apatites. Key Eng. Mater. 2005, 284-286, 3-6. [CrossRef]

207. Busenberg, E.; Plummer, L.N. Thermodynamics of magnesian calcite solid-solutions at $25^{\circ} \mathrm{C}$ and 1 atm total pressure. Geochim. Cosmochim. Acta 1989, 53, 1189-1208. [CrossRef]

208. Bischoff, W.D.; Mackenzie, F.T.; Bishop, F.C. Stabilities of synthetic magnesian calcites in aqueous solution: Comparison with biogenic materials. Geochim. Cosmochim. Acta 1987, 51, 1413-1423. [CrossRef]

209. Bertram, M.A.; Mackenzie, F.T.; Bishop, F.C.; Bischoff, W.D. Influence of temperature on the stability of magnesian calcite. Am. Mineral. 1991, 76, 1889-1896.

210. Tribble, J.S.; Arvidson, R.S.; Lane, M.; Mackenzie, F.T. Crystal chemistry, and thermodynamic and kinetic properties of calcite, dolomite, apatite, and biogenic silica: Applications to petrologic problems. Sediment. Geol. 1995, 95, 11-37. [CrossRef]

211. Michałowski, T.; Asuero, A.G. Thermodynamic Modelling of Dolomite Behavior in Aqueous Media. J. Thermodyn. 2012, 2012, 1-12. [CrossRef]

212. Moomaw, A.S.; Maguire, M.E. The unique nature of $\mathrm{Mg}^{2+}$ channels. Physiology (Bethesda) 2008, $23,275-285$. [CrossRef]

213. Usdovski, E. Synthesis of dolomite and geochemical implications. In Dolomites: A Volume in Honour of Dolomieu; Purser, B.H., Tucker, M.E., Zenger, D.H., Eds.; Blackwell Sci. Publ.: Oxford, UK, 1994; pp. 345-360.

214. Sherman, L.A.; Barak, P. Solubility and dissolution kinetics of dolomite in $\mathrm{Ca}-\mathrm{Mg}-\mathrm{HCO}_{3} / \mathrm{CO}_{3}$ solutions at $25^{\circ} \mathrm{C}$ and $0.1 \mathrm{MPa}$ carbon dioxide. Soil Sci. Soc. Am. J. 2000, 64, 1959-1968. [CrossRef]

215. Pabst, A. The Crystallography Structure of Eitelite, $\mathrm{Na}_{2} \mathrm{Mg}\left(\mathrm{CO}_{3}\right)_{2}$. Am. Miner. 1973, 58, 211-217.

216. Effenberger, H. Crystal-structure and infrared-absorption spectrum of synthetic monohydrocalcite, $\mathrm{CaCO}_{3} \cdot \mathrm{H}_{2} \mathrm{O}$. Monatsh. Chem. 1981, 112, 899-909. [CrossRef]

217. Swainson, I. P. The structure of monohydrocalcite and the phase composition of the beachrock deposits of Lake Butler and Lake Fellmongery, South Australia. Am. Mineral. 2008, 93, 1014-1018. [CrossRef]

218. Bachra, B.N.; Trautz, O.R.; Simon, S.L. Precipitation of calcium carbonates and phosphates. I. Spontaneous precipitation of calcium carbonates and phosphates under physiological conditions. Arch. Biochem. Biophys. 1963, 103, 124-138. [CrossRef]

219. Ferguson, J.F.; McCarty, P.L. The Precipitation of PhosDhates from Fresh Waters and Waste Waters; Tech Report No. 120; Department of Civil Engineering, Stanford University: Stanford, CA, USA, 1969.

220. Kibalczyc, W.; Christoffersen, J.; Christoffersen, M.R.; Zielenkiewicz, A.; Zielenkiewicz, W. The effect of magnesium-ions on the precipitation of calcium phosphates. J. Cryst. Growth 1990, 106, 355-366. [CrossRef]

221. Bachra, B.N.; Trautz, O.R.; Simon, S.L. Precipitation of calcium carbonates and phosphates-III. Arch. Oral Biol. 1965, 10, 731-738. [CrossRef]

222. Mekmene, O.; Quillard, S.; Rouillon, T.; Bouler, J.-M.; Piot, M.; Gaucheron, F. Effects of pH and Ca/P molar ratio on the quantity and crystalline structure of calcium phosphates obtained from aqueous solutions. Dairy Sci. Technol. EDP Sci./Springer 2009, 89, 301-316. [CrossRef]

223. Terpstra, R.A.; Driessens, F.C.M. Magnesium in tooth enamel and synthetic apatites. Calcif. Tissue Int. 1986, 39, 348-354. [CrossRef]

224. Martens, C.S.; Harriss, R.C. Inhibition of apatite precipitation in the marine environment by magnesium ions. Geochim. Cosmochim. Acta 1970, 34, 621-625. [CrossRef]

225. Termine, J.D.; Conn, K.M. Inhibition of apatite formation by phosphorylated metabolites and macromolecules. Calcif. Tiss. Res. 1976, 22, 149-157. [CrossRef]

226. Posner, A.S.; Betts, F.; Blumenthal, N.C. Role of ATP and Mg in the stabilization of biological and synthetic amorphous calcium phosphates. Calcif. Tissue Res. 1977, 22, 208-212. [CrossRef]

227. Rey, C.; Trombe, J.C.; Montel, G. Some features of the incorporation of oxygen in different oxidation states in the apatitic lattice-III Synthesis and properties of some oxygenated apatites. J. Inorg. Nucl. Chem. 1978, 40, 27-30. [CrossRef]

228. Pan, Y.; Fleet, M.E. Compositions of the Apatite-Group Minerals: Substitution Mechanisms and Controlling Factors. Rev. Mineral. Geochem. 2002, 48, 13-49. [CrossRef] 
229. Mason, A.Z.; Nott, J.A. The role of intracellular biomineralized granules in the regulation and detoxification of metals in gastropods with special reference to the marine prosobranch Littorina littorea. Aquat. Toxicol. 1981, 1, 239-256. [CrossRef]

230. Nott, J.A.; Langston, W.J. Cadmium and the phosphate granules in Littorina littorea. J. Mar. Biol. Assoc. UK 1989, 69, 219-227. [CrossRef]

231. Bonucci, E.; Derenzini, M.; Marinozzi, V. The organic-inorganic relationship in calcified mitochondria. J. Cell. Biol. 1973, 59, 185-211. [CrossRef]

232. Baartscheer, A.; Schumacher, C.A.; Coronel, R.; Fiolet, J.W.T. The driving force of the $\mathrm{Na}^{+} / \mathrm{Ca}^{2+}$-exchanger during metabolic inhibition. Front. Physiol. 2011, 2, 1-7. [CrossRef] [PubMed]

233. Griffiths, E. J.; Halestrap, A. P. Mitochondrial non-specific pores remain closed during cardiac ischaemia, but open upon reperfusion. Biochem. J. 1995, 307, 93-98. [CrossRef]

234. Bernardi, P. Mitochondrial transport of cations: Channels, exchangers, and permeability transition. Physiol. Rev. 1999, 79, 1127-1155. [CrossRef]

235. Meldrum, D.R.; Cleveland, J.C.J.; Mitchell, M.B.; Sheridan, B.C.; Gamboni-Robertson, F.; Harken, A.H.; Banerjee, A. Protein kinase $\mathrm{C}$ mediates $\mathrm{Ca}^{2+}$-induced cardioadaptation to ischemia-reperfusion injury. Am. J. Physiol. 1996, 271, R718-R726. [CrossRef]

236. Miyawaki, H.; Zhou, X.; Ashraf, M. Calcium preconditioning elicits strong protection against ischemic injury via protein kinase C signaling pathway. Circ. Res. 1996, 79, 137-146. [CrossRef]

(C) 2020 by the authors. Licensee MDPI, Basel, Switzerland. This article is an open access article distributed under the terms and conditions of the Creative Commons Attribution (CC BY) license (http://creativecommons.org/licenses/by/4.0/). 